\title{
Understanding the Drivers of Household Energy Spending: Micro Evidence for Latin America
}

* IDB Invest, Bogota, Colombia. Contact: rjmori@gmail.com

** Inter-American Development Bank, Washington D.C., USA

\begin{abstract}
The paper investigates the determinants of household energy spending and energy budget shares, with a focus on understanding their non-linear relationship with income, and the presence of economies of scale. The analysis is based on a unique, harmonized collection of official household surveys from 13 Latin American countries. This dataset allows distinguishing between expenditures on electricity, domestic gas, and fuel for private transportation, providing a comprehensive distributional view of the energy spending profile of the residential sector. The estimated empirical Engel curves behave similarly; however, the derived income elasticities show marked distinctions by fuel, and their actual values depend on the households' relative position over the income distribution. For electricity, the elasticity tends to increase in income but stabilize at the wealthiest segments. For gas and transport fuel, it decreases under different income paths. In this dataset, the examination returns income elasticities on the $(0,1)$ interval, suggesting that energy commodities are necessity goods. However, the distribution of aggregate energy expenditure needs to be considered. Specifically, there is a great concentration among the richer groups, particularly for transport fuels, where the top quintile gathers more than half of the aggregate spending. The results also indicate economies of scale - for electricity and domestic gas - with respect to family-age composition, and to a lesser extent with respect to dwelling size. In the case
\end{abstract}


of electricity, these economies are more pronounced for richer households. These results join the previous literature in emphasizing the relevance of accounting for household demographic and socioeconomic trends for energy management.

Keywords: Energy expenditures, Engel curves, household surveys, Latin American countries.

JEL Classification: D12, Q41.

\section{Introduction}

Energy commodities are essential household needs which consequently represent a relevant component of the household budget (e.g., Fankhauser \& Tepic, 2007; Bacon et al., 2010; Advani et al., 2013). Lighting, heating, refrigeration, cooking, and transportation exemplify some of the basic activities that require a reliable and affordable supply of modern energy sources. At the same time, environmental considerations require disciplining energy consumption through a variety of measures that directly affect the residential sector, including energy conservation and efficiency measures, as well as pricing mechanisms (e.g., Meyers et al., 2003; Geller et al., 2006). In this context, understanding the factors that determine energy expenditure and their interrelations constitute building blocks for policies contributing to balance the trade-offs between meeting households' basic needs and reducing the environmental impact.

Related literature can be broadly grouped into studies addressing the determinants of energy expenditure - or energy budget shares - and studies on energy consumption at the household level (e.g., Meier et al., 2013; Cayla et al., 2011; Advani et al., 2013; Baker et al., 1989; Heltberg, 2004; Fouquet, 2014; Pachauri \& Jiang, 2008; Hanna \& Oliva, 2015). Overall, their findings indicate the relevant roles of economic and noneconomic factors. In particular, economic factors - that is, income and energy prices - have received greater attention as they determine the key budgetary restrictions for consumption and expenditure decisions. Accordingly, previous studies show their significant effects on household energy demand and expenditures, although with noticeable heterogeneity between income groups. For example, the income elasticity estimated by Baker et al. (1989) shows substantial differences between income groups in the United Kingdom, from -0.172 in the top decile to 0.177 in the bottom decile.

On the other hand, energy demand actually derives from noneconomic factors - such as household size, location (urban/rural), holding of appliances, dwelling size, and temperaturewhich have proven to have a sizeable impact on energy spending (e.g., Poyer et al., 1997; Estiri, 2015; Longhi, 2015). For example, in the case of the United Kingdom, Longhi (2015) indicates that accommodation characteristics contribute up to 20 percent of gas expenditures and up to 10 percent for electricity.

In light of this evidence and as a response to improvements in living standards, along with the increasing adoption of durable appliances and vehicles, it is expected that future incremental global energy demand will come mainly from the developing world, with the residential sector being a central player (BP, 2016; Wolfram et al., 2012). However, relatively fewer studies have focused on the household sector of Latin America, a region which has experienced a dynamic economic progress over the last decades (see Navajas, 2009, for the case of Gas in Argentina, and Foster et al., 2000, for overall energy consumption in Guatemala). In a related multi-country study, which includes Brazil, Winkler et al. (2011) discuss trends in access to and affordability of electricity services, emphasizing the increasing policy relevance of the latter for tackling energy poverty.

Besides, a line of study which has received noticeably less attention, focuses on economies of scale (EOS) in energy consumption. EOS is of interest in the broader literature studying household budget allocation (Benus et al., 1976; Nelson, 1988; Deaton \& Paxson, 1998), and, 
as an extension of this literature, the presence of EOS is plausible for energy consumption, with relevant policy implications. EOS can appear in different ways; for example, consumption of cooking fuels may increase less than proportionally to family size. Electricity and gas consumption for lighting and heating/cooling may increase linearly with dwelling size. To the best of our knowledge, only EOS from family age composition -over residential energy use and expenditure- has been studied by Ironmonger et al. (1995) and Underwood \& Zahran (2015) in Australia, and the United States, respectively. The authors find significant economies of scale, but at the same time they alert that the observed trends toward smaller family size would overweight such effects, placing an upward pressure on carbon dioxide emissions.

In this paper, we investigate the determinants of energy expenditures and energy budget shares at the household level, with a focus on evaluating their relationship with income and the existence of EOS with respect to family age composition and dwelling size. The study exploits a cross-sectional dataset that harmonizes expenditure headings across official household surveys from 13 Latin American countries. This dataset allows distinguishing expenditures in electricity, domestic gas and fuels for private transportation, providing an extensive coverage of the energy expenditure profile of Latin American households by income group. In addition to containing a rich set of covariates, the dataset identifies detailed indicators of household geographical location, allowing us to control for a variety of omitted and non-observed factors.

Our results suggest the presence of EOS for family size and dwelling size, although EOS for the latter are considerably smaller. The estimated Engel curves behave similarly between fuels; however, the derived income elasticities show distinctive patterns by fuel over the income distribution. For electricity, this elasticity tends to increase in income, stabilizing at the richest groups. For gas and transport fuel, the elasticity decreases but follows different patterns along the income distribution. Conditional on using the fuel, our examination returns income elasticities that move on the $(0,1)$ interval. While this result tags energy commodities as necessity goods, it is important to consider that the richest income groups gather half the aggregate energy expenditure and that such concentration is even more pronounced for transport fuels.

The paper makes three main empirical and policy contributions. First, it exploits an original and detailed systematization of household surveys from a set of countries that concentrate over 70 percent of the population in Latin America and the Caribbean (LAC). To the best of our knowledge, no previous research has provided comparably extensive coverage of countries and fuels in the LAC's household sector. Second, in examining EOS with respect to family age composition and dwelling size, the paper provides insights on the potential implications of global demographic and construction trends on the energy sector. Third, the paper is timely as it addresses the distribution of energy expenditure and energy affordability in a context of great attention to reforming energy subsidies in developing countries (Coady et al., 2017; Di Bella et al., 2015). In this sense, the findings may contribute to inform about the potential implications of these reforms in the residential sector. Besides, the distributive approach of the paper is relevant for evaluating the household's ability to afford a minimum level of energy services, which is a sensitive contemporary issue in developing and developed countries. ${ }^{1}$

In section 2, we discuss the data and the variables to be examined. Section 3 provides a distributional descriptive, unconditional review of the patterns of energy expenditure by income decile. In section 4, we present our econometric approach. In section 5, we describe the main estimation results. Section 6 concludes with a discussion of our results and their potential implications.

$1 \quad$ See, for example: "Where the Poor Spend More Than 10 Percent of Their Income on Energy? Hint: Almost Everywhere in the United States," in The Atlantic, June 8, 2016; and "Over 300,000 Poverty-Hit German Homes Have Power Cut Off Each Year," in The Local, March, 2, 2017. 


\section{Data, Variables, and Summary Statistics}

The analysis is based on a cross-section of national household expenditure surveys that covers close to 183,000 households in 13 countries. ${ }^{2}$ These surveys are performed by the national statistical agencies and were selected because they are specifically designed and implemented to capture household expenditures, as well as their socioeconomic characteristics. Annex A provides details on the surveys used in this study. The data include only those households that reported expenditures on at least one source of energy. In the case of electricity, we only account for household with on-grid connection. To reduce the presence of outliers, we trimmed the sample by dropping the 1 percent of households at the lowest and highest income and expenditure levels. $^{3}$

Since different products or services have a different periodicity of purchase, the data were multiplied by the corresponding factor to express expenditures in annual terms (i.e., the monthly value would be multiplied by 12). Further, given that national surveys are available for different years, all values were extrapolated to 2014 based on the change in the current household final consumption expenditure per capita (c). For example, in the Dominican Republic, where the last survey available is for 2007 , all values were multiplied by the factor $c_{114} / c_{107}$. This adjustment accounts for inflation and real growth in residential consumption. The data on households' final consumption were obtained from the World Development Indicators database (WDI). Note that the extrapolation affects only the absolute expenditure amount, not the expenditure structure. All expenditures are expressed in U.S. dollars and adjusted for purchasing power parity (PPP), using exchange rates provided also in the WDI: official average exchange rates and PPP conversion factors for private consumption. Similarly, the population sample weights in the surveys were updated to account for population growth in urban and rural areas. That is, for years prior to 2014, the weights were adjusted for the annual rate of growth of the urban and rural population.

Harmonization of the income and expenditure headings closely follows the International Comparison Program classification, which is broadly used in national household surveys. This classification allows for a whole picture of the household budget and income structure by relevant items/sources. However, to reduce potential measurement problems and to reflect household economic conditions, instead of income, we use total annual spending as the main dependent variable. This variable was constructed taking the same expenditure headings in all countries. These headings include food, dwelling maintenance, transportation, communications, entertainment, clothing, health, education, and other monthly expenditures. ${ }^{4}$ In this paper, income groups (i.e., quintiles and deciles) are defined based on the distribution of per capita household expenditure within each country. In the case of energy commodities, we distinguish between domestic energy and transport fuel. Domestic energy includes electricity, natural gas, and other fuels (such as wood, coal, and kerosene). Transport fuel aggregates all fuels reported by the household, including gasoline, diesel, and liquefied petroleum gas, among others. ${ }^{5}$

Other socioeconomic characteristics were selected based on the literature. Table 1 presents the descriptive statistics. The table shows that traditional energy sources have a very low representation in the family budget. Since those are mostly non-commercial energy sources, it is

2 The countries included in this data set are Bolivia, Brazil, Costa Rica, Dominican Republic, Ecuador, Guatemala, Honduras, Jamaica, Mexico, Nicaragua, Peru, Paraguay, and Uruguay. Other countries were dropped because of lack of some covariates.

3 In the case of Bolivia, we drop an additional top 1\% since those observations presented unusual high values for income.

4 This measure of total household expenditure includes monetary and nonmonetary reported consumption. Nonmonetary includes in-kind donations, payments or subsidies, and so forth.

5 It is not possible to separate expenditures homogeneously by product or even category across all countries. Therefore, expenditures on gas and electricity include associated expenditures, such as the purchase and installation of meters, meter reading, storage containers, and outstanding charges. In the case of Bolivia, Honduras, and Nicaragua, information on transport fuel expenditures aggregates all transport fuels into one category. 
difficult to capture their value in expenditure surveys; therefore, we focus the regression analysis on commercial energy sources: electricity, gas, and fuels for private transportation.

With regard to domestic gas, it is important to mention that, in this sample, the reported expenditures do not distinguish between bottled gas versus network. However, network gas is only present in Brazil, Mexico, and Peru, having a small market share. For example, in Brazil, the residential sector account for around $1.4 \%$ of consumption of natural gas in 2015 (according to its national energy balance). Further, less than $1 \%$ of the household in the survey under analysis have piped connections. This implies that even distinguishing the type of domestic gas, we would probably have a small sample to perform the analysis.

The dataset and programs files are available for replication, please see the online material.

Table 1. Descriptive Statistics

\begin{tabular}{|c|c|c|c|c|c|}
\hline Variable & Obs & Mean & Pct 1 & Pct99 & $\mathrm{SD}$ \\
\hline Share of electricity expenditures on income $(\%)$ & 164,468 & 3.60 & 0.30 & 18.17 & 3.72 \\
\hline Share of household domestic gas expenditures $(\%)$ & 144,978 & 2.23 & 0.12 & 12.31 & 2.61 \\
\hline Share of expenditures on other domestic fuels $(\%)$ & 21,007 & 2.74 & 0.04 & 19.52 & 4.03 \\
\hline Share of transportation expenditures $(\%)$ & 54,487 & 7.43 & 0.49 & 32.49 & 6.67 \\
\hline Annual household expenditures on electricity (PPP US\$) & 182,851 & 444 & - & 2,560 & 561 \\
\hline Annual household expenditures on domestic gas (PPP US\$) & 182,851 & 188 & - & 809 & 206 \\
\hline Annual household expenditures on other fuels (PPP US\$) & 182,851 & 28 & - & 651 & 147 \\
\hline Annual household expenditures on transportation fuels (PPP US\$) & 182,851 & 509 & - & 6,290 & 1,358 \\
\hline Annual household total expenditures (PPP US\$) & 182,851 & 16,878 & 1,555 & 82,496 & 16,607 \\
\hline Area of habitation (urban $=1$, rural- 0 ) & 182,851 & 0.74 & 0.00 & 1.00 & 0.44 \\
\hline Household size (\#) & 182,851 & 3.77 & 1.00 & 10.00 & 1.93 \\
\hline Dwelling Size (\# rooms) & 182,851 & 4.10 & 1.00 & 10.00 & 2.47 \\
\hline Ownership of a refrigerator (ownership=1) & 182,851 & 0.75 & 0.00 & 1.00 & 0.43 \\
\hline Ownership of a computer (ownership=1) & 182,851 & 0.25 & 0.00 & 1.00 & 0.43 \\
\hline Ownership of a TV (ownership=1) & 182,851 & 0.90 & 0.00 & 1.00 & 0.30 \\
\hline Ownership of an automobile (ownership=1) & 182,851 & 0.21 & 0.00 & 1.00 & 0.41 \\
\hline Ownership of the dwelling (ownership=1) & 182,851 & 0.70 & 0.00 & 1.00 & 0.46 \\
\hline Education level (from $1=$ primary school to $6=$ university or higher) & 182,851 & 2.88 & 1.00 & 6.00 & 1.32 \\
\hline Age of the household head & 182,851 & 48.37 & 21.00 & 86.00 & 15.82 \\
\hline Gender of the household head (male $=1$, female $=0$ ) & 182,851 & 0.72 & 0.00 & 1.00 & 0.45 \\
\hline
\end{tabular}

Source: Own elaboration.

Note: The column "Obs" counts only households with positive reported values and electricity grid connection. All values are weighted using the population expansion factor.

\section{Descriptive Patterns of Energy Expenditure by Income Decile}

This section pools our underlying microdata to provide a descriptive view of some patterns that characterize energy spending in the Latin America region. An important consideration is that those patterns can be examined excluding, or not, zero reported spending. In both cases, it is assumed that zero does not reflect underreporting, but the non-consumption of a given good or service. Therefore, excluding zeros provides averages that more closely reflect the patterns among the users. However, this approach precludes constructing an average synthetic budget structure that takes into account multiple fuels for a given population group (because users may differ for different fuels). For this reason, some researchers prefer to compute ab- 
solute expenditures and their shares in total expenditures across all households regardless of whether they consume a given fuel (see for example Bacon et al., 2010; and Advani et al., 2013). In this section, we follow this practice except for Table 3, which provides some contrasting results.

Figure 1 presents the composition of annual household energy spending, in U.S. dollars, by expenditure decile. Along the income distribution, the composition of energy spending changes markedly, emerging great differences between deciles; the richest income groups spend almost seven times what the poorest groups spend. The greatest increase is observed for liquid fuels for private transportation, which outdoes that of domestic fuels. Indeed, in the first decile, electricity and domestic gas explain around 90 percent of the household energy budget. In the richest group, such share falls to around 32 percent, being displaced by transport fuels. Figure 1 also shows that, in this sample, expenditure on "other" fuels is not significant. This is the main reason why those fuels are not included in the regression analysis in the following sections.

Figure 1. Composition of Household Energy Spending by Expenditure Decile

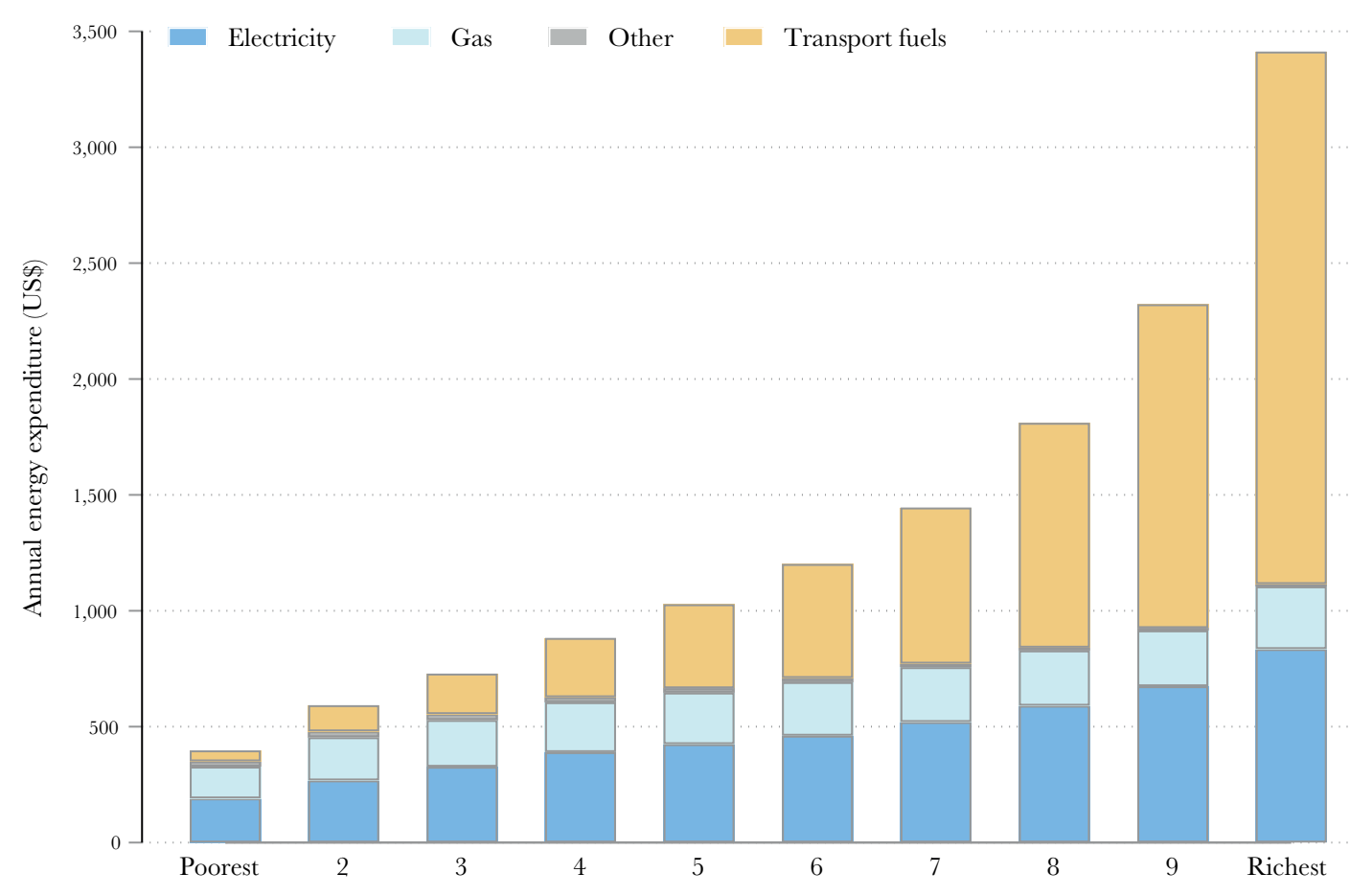

Source: Own elaboration.

Note: Includes zero reported energy expenditures. Values are weighted using the population expansion factor. In PPP US\$.

For public policy considerations on energy affordability, it is also interesting to express previous expenditures in relative terms, as shares of the household budget (Winkler et al., 2011). Figure 2 plots the trend lines of these energy shares by decile. In contrast to the previous figure - where all energy expenditures increase in income- the associated budget shares for electricity and gas tend to decrease toward the right of the income distribution. Only the budget share of transport fuels increases, reaching a greater share than domestic energy. That is, while the budget share of domestic fuel decreases along the income distribution, the total energy budget share remains roughly stable, a result of the increasing budget allocation for transport fuels. These interrelations between different types of energy seem to explain the S-shaped curve in total energy (bold blue line), portraying dissimilar energy spending patterns between income groups. 
According to these patterns, electricity and domestic gas may be considered necessity goods, while spending on transport fuels seems to have the characteristics of a luxury good. As affordability concerns are not material at higher income levels, changes in expenditures on electricity and gas are of interest at the lower income deciles. Together, these two energy sources constitute around 8 percent of household annual total expenditure in the first decile, showing greater vulnerability than richer segments.

Figure 2. Household Energy Budget Share by Expenditure Decile

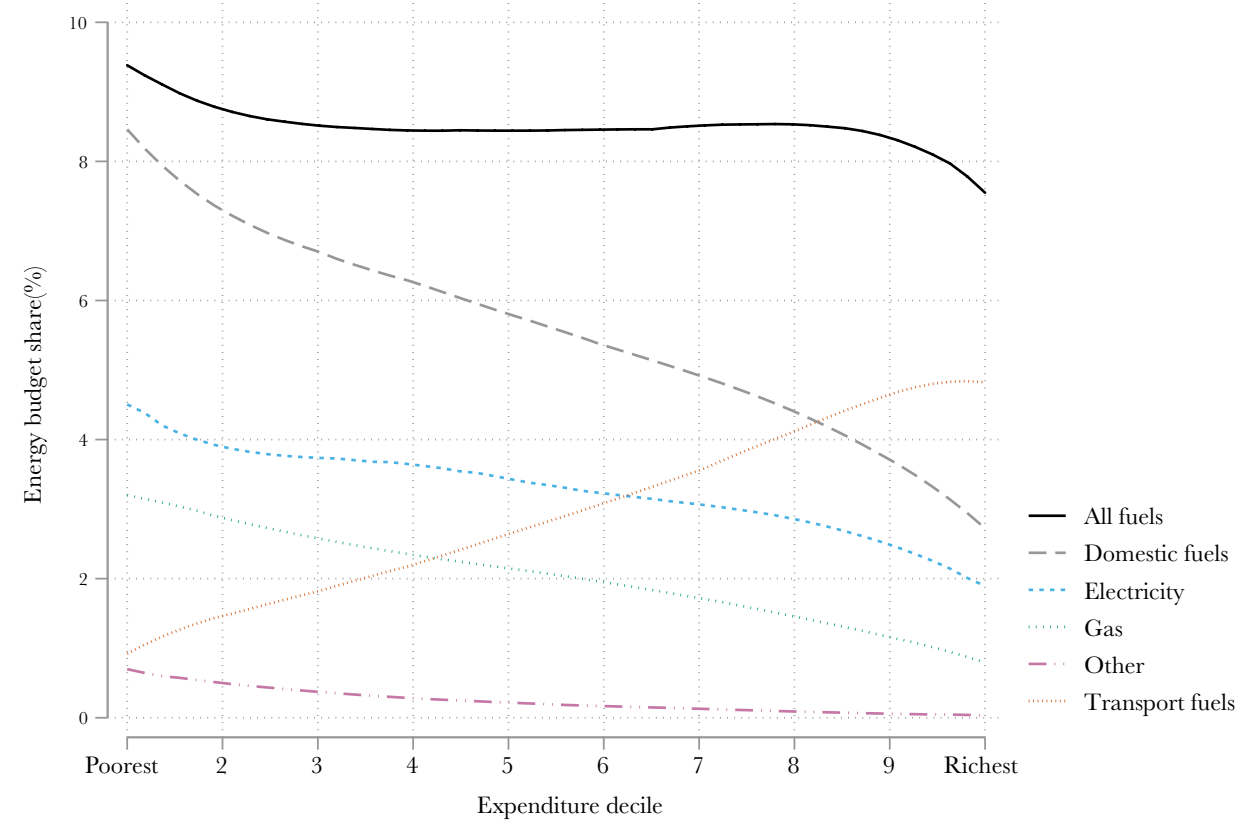

Source: Own elaboration.

Note: Includes zero reported energy expenditures. Values are weighted using the population expansion factor.

Table 2. Energy Budget Shares, by Total Household Expenditure Quintile (\%, including zero reported energy expenditures)

\begin{tabular}{llccccc}
\hline \multirow{2}{*}{ Country } & & \multicolumn{5}{c}{ Expenditure quintile, pc hh } \\
\cline { 3 - 7 } Bolivia & All & 3.4 & 3.7 & 3.7 & 4.0 & 3.8 \\
& Electricity & 1.9 & 1.9 & 2.0 & 2.0 & 1.8 \\
& Gas & 1.0 & 0.8 & 0.7 & 0.6 & 0.4 \\
& Transport fuels & 0.5 & 1.0 & 1.0 & 1.4 & 1.6 \\
& & & & & & \\
\multirow{5}{*}{ Brazil } & All & 9.6 & 8.3 & 8.2 & 8.0 & 7.1 \\
& Electricity & 5.1 & 4.4 & 3.8 & 3.3 & 2.2 \\
& Gas & 3.6 & 2.2 & 1.6 & 1.0 & 0.5 \\
& Transport fuels & 0.9 & 1.8 & 2.8 & 3.8 & 4.4 \\
& & & & & & \\
& All & 11.4 & 9.5 & 8.6 & 8.2 & 6.7 \\
& Electricity & 5.3 & 3.9 & 3.2 & 2.4 & 1.6 \\
& Gas & 1.3 & 0.7 & 0.5 & 0.3 & 0.1 \\
& Transport fuels & 4.8 & 4.9 & 4.9 & 5.5 & 5.0 \\
\hline
\end{tabular}


Table 2 (continued). Energy Budget Shares, by Total Household Expenditure Quintile (\%, including zero reported energy expenditures)

\begin{tabular}{|c|c|c|c|c|c|c|}
\hline \multirow{2}{*}{ Country } & \multirow{2}{*}{ Fuel } & \multicolumn{5}{|c|}{ Expenditure quintile, pc hh } \\
\hline & & Poorest & Q2 & Q3 & Q4 & Richest \\
\hline Dominican & All & 7.5 & 7.5 & 7.6 & 8.2 & 9.5 \\
\hline \multirow[t]{3}{*}{ Republic } & Electricity & 2.1 & 2.3 & 2.3 & 2.5 & 2.5 \\
\hline & Gas & 3.4 & 2.8 & 2.4 & 1.9 & 1.3 \\
\hline & Transport fuels & 2.1 & 2.4 & 2.9 & 3.8 & 5.7 \\
\hline \multirow[t]{4}{*}{ Ecuador } & All & 2.8 & 2.8 & 2.8 & 3.1 & 3.5 \\
\hline & Electricity & 1.8 & 1.7 & 1.7 & 1.7 & 1.6 \\
\hline & Gas & 0.7 & 0.5 & 0.4 & 0.3 & 0.2 \\
\hline & Transport fuels & 0.3 & 0.5 & 0.7 & 1.0 & 1.8 \\
\hline \multirow[t]{4}{*}{ Guatemala } & All & 7.6 & 6.9 & 8.0 & 8.6 & 9.0 \\
\hline & Electricity & 6.7 & 4.8 & 4.5 & 4.2 & 3.5 \\
\hline & Gas & 0.3 & 1.3 & 2.1 & 2.2 & 1.5 \\
\hline & Transport fuels & 0.7 & 0.9 & 1.4 & 2.2 & 4.0 \\
\hline \multirow[t]{4}{*}{ Honduras } & All & 4.6 & 4.8 & 5.5 & 6.5 & 8.8 \\
\hline & Electricity & 4.3 & 3.6 & 3.3 & 3.0 & 3.0 \\
\hline & Gas & 0.3 & 0.8 & 1.2 & 1.4 & 0.8 \\
\hline & Transport fuels & & 0.5 & 1.0 & 2.1 & 5.0 \\
\hline \multirow[t]{4}{*}{ Jamaica } & All & 12.3 & 11.3 & 12.0 & 11.4 & 12.0 \\
\hline & Electricity & 8.8 & 7.5 & 7.8 & 6.4 & 5.4 \\
\hline & Gas & 3.2 & 3.1 & 2.9 & 2.5 & 1.7 \\
\hline & Transport fuels & 0.3 & 0.7 & 1.3 & 2.5 & 4.9 \\
\hline \multirow[t]{4}{*}{ Mexico } & All & 9.3 & 10.1 & 10.3 & 11.0 & 10.7 \\
\hline & Electricity & 3.8 & 3.2 & 2.7 & 2.6 & 1.9 \\
\hline & Gas & 3.3 & 3.6 & 3.4 & 2.8 & 1.9 \\
\hline & Transport fuels & 2.2 & 3.3 & 4.2 & 5.6 & 6.8 \\
\hline \multirow[t]{4}{*}{ Nicaragua } & All & 5.0 & 6.5 & 7.4 & 8.2 & 10.6 \\
\hline & Electricity & 3.2 & 3.5 & 3.3 & 3.3 & 3.4 \\
\hline & Gas & 1.6 & 2.4 & 2.6 & 2.5 & 1.8 \\
\hline & Transport fuels & 0.2 & 0.7 & 1.5 & 2.4 & 5.3 \\
\hline \multirow[t]{4}{*}{ Peru } & All & 7.3 & 6.2 & 5.7 & 5.1 & 4.8 \\
\hline & Electricity & 3.4 & 2.7 & 2.8 & 2.7 & 2.4 \\
\hline & Gas & 3.3 & 3.0 & 2.4 & 1.9 & 1.3 \\
\hline & Transport fuels & 0.6 & 0.5 & 0.5 & 0.6 & 1.2 \\
\hline
\end{tabular}


Table 2 (continued). Energy Budget Shares, by Total Household Expenditure Quintile (\%, including zero reported energy expenditures)

\begin{tabular}{|c|c|c|c|c|c|c|}
\hline \multirow{2}{*}{ Country } & \multirow{2}{*}{ Fuel } & \multicolumn{5}{|c|}{ Expenditure quintile, pc hh } \\
\hline & & Poorest & Q2 & Q3 & $Q^{4}$ & Richest \\
\hline \multirow{4}{*}{ Paraguay } & All & 5.6 & 6.5 & 7.4 & 7.7 & 8.6 \\
\hline & Electricity & 2.3 & 2.5 & 2.8 & 2.8 & 2.7 \\
\hline & Gas & 0.9 & 1.6 & 1.4 & 1.5 & 1.1 \\
\hline & Transport fuels & 2.4 & 2.5 & 3.1 & 3.5 & 4.8 \\
\hline \multirow[t]{4}{*}{ Uruguay } & All & 16.0 & 14.6 & 12.4 & 10.8 & 9.8 \\
\hline & Electricity & 10.0 & 9.0 & 7.4 & 6.0 & 4.5 \\
\hline & Gas & 4.2 & 3.0 & 2.3 & 1.7 & 1.1 \\
\hline & Transport fuels & 1.8 & 2.6 & 2.7 & 3.2 & 4.2 \\
\hline Pooled & All & 8.9 & 8.3 & 8.3 & 8.4 & 7.9 \\
\hline \multirow[t]{3}{*}{ Sample } & Electricity & 4.4 & 3.8 & 3.4 & 3.0 & 2.2 \\
\hline & Gas & 3.2 & 2.5 & 2.1 & 1.6 & 1.0 \\
\hline & Transport fuels & 1.3 & 2.0 & 2.9 & 3.8 & 4.8 \\
\hline
\end{tabular}

Source: Own elaboration.

Note: Includes zero reported energy expenditures. All values are weighted using the population expansion factor.

To look at the heterogeneity between countries, Table 2 provides the energy budget share by quintile for each country in the sample. The greatest weight of domestic fuels (electricity and gas) in the poorest quintile is observed in Uruguay (14 percent), followed by Jamaica (12 percent), Brazil (8.7 percent), Guatemala (7 percent), Peru (6.7 percent), and Costa Rica (6.6 percent); for the rest of the countries, it is less than 5 percent. To evaluate the degree of vulnerability that these figures represent, we can consider reference estimations. For example, pooling the calculations of different studies, the energy budget share is around 2.1 percent on average and goes up to 17.5 percent for the poorest quintile (Jamasb \& Meier, 2010; Meier et al., 2013; Bacon et al., 2010). By contrast, Fankhauser \& Tepic (2007), based on a compilation from different institutions, use as a general benchmark 10 percent of household income for electricity and 10 percent for heating. One of the lowest thresholds for all household energy expenditures is that of the United States, where it is around 6 percent of income. ${ }^{6}$

How much do these results change if we account only for households with positive expenditures? Table 3 presents the average shares conditional on reporting positive expenditures, showing that, as expected, the energy shares increase in all countries. The increments are more pronounced in the case of electricity and transport fuels for the lower income groups. In the case of the Dominican Republic, the electricity share, in the 1st quintile, goes from 2.1 percent to 4.7 percent. Since informal electricity connections con explain zero spending, these figures more closely reflect the affordability of the poorest households who pay for the services. Regarding transport fuels, Table 3 indicates that households dedicate a sizeable share of their budget to such fuels. Notice, however, that only 12.9 percent of households in the poorest quintile report positive expenditures, suggesting that the take-up is relatively low (see Table 4).

6 https://www.nyserda.ny.gov/About/Newsroom/2016-Announcements/2016-05-19-Governor-Cuomo-Announces-New-Energy-Affordability-Policy; https://www.theatlantic.com/business/archive/2016/06/energy-poverty-low-income-households/486197/. 
Table 3. Energy Budget Shares, by Total Household Expenditure Quintile (\%, excluding zero reported energy expenditures)

\begin{tabular}{|c|c|c|c|c|c|c|}
\hline \multirow{2}{*}{ Country } & \multirow{2}{*}{ Fuel } & \multicolumn{5}{|c|}{ Expenditure quintile, pc hh } \\
\hline & & Poorest & Q2 & Q3 & $Q^{4}$ & Richest \\
\hline \multirow[t]{3}{*}{ Bolivia } & Electricity & 1.9 & 2.0 & 2.0 & 2.1 & 1.9 \\
\hline & Gas & 1.5 & 1.0 & 0.8 & 0.6 & 0.4 \\
\hline & Transport fuels & 4.0 & 4.3 & 3.6 & 4.0 & 3.8 \\
\hline \multirow[t]{3}{*}{ Brazil } & Electricity & 5.8 & 4.8 & 4.1 & 3.4 & 2.3 \\
\hline & Gas & 4.0 & 2.3 & 1.6 & 1.1 & 0.6 \\
\hline & Transport fuels & 11.2 & 9.6 & 9.5 & 8.8 & 7.0 \\
\hline \multirow[t]{3}{*}{ Costa Rica } & Electricity & 5.3 & 3.9 & 3.2 & 2.4 & 1.6 \\
\hline & Gas & 2.2 & 1.4 & 1.1 & 0.7 & 0.4 \\
\hline & Transport fuels & 10.2 & 8.5 & 8.4 & 7.9 & 6.7 \\
\hline Dominican & Electricity & 4.7 & 4.2 & 3.6 & 3.6 & 3.1 \\
\hline \multirow[t]{2}{*}{ Republic } & Gas & 4.0 & 3.4 & 2.9 & 2.6 & 2.1 \\
\hline & Transport fuels & 9.5 & 8.7 & 9.2 & 10.5 & 10.8 \\
\hline \multirow[t]{3}{*}{ Ecuador } & Electricity & 2.3 & 2.1 & 2.0 & 1.9 & 1.6 \\
\hline & Gas & 0.8 & 0.6 & 0.5 & 0.4 & 0.3 \\
\hline & Transport fuels & 4.2 & 3.8 & 3.8 & 3.9 & 3.9 \\
\hline \multirow[t]{3}{*}{ Guatemala } & Electricity & 7.0 & 5.1 & 5.0 & 4.6 & 3.7 \\
\hline & Gas & 8.8 & 5.5 & 4.2 & 3.2 & 2.1 \\
\hline & Transport fuels & 10.3 & 7.3 & 6.5 & 6.0 & 6.7 \\
\hline \multirow[t]{3}{*}{ Honduras } & Electricity & 4.3 & 3.7 & 3.6 & 3.4 & 3.2 \\
\hline & Gas & 10.6 & 7.4 & 4.3 & 3.2 & 1.9 \\
\hline & Transport fuels & & 15.4 & 15.0 & 14.0 & 11.1 \\
\hline \multirow[t]{3}{*}{ Jamaica } & Electricity & 10.9 & 8.6 & 8.4 & 7.0 & 5.6 \\
\hline & Gas & 6.7 & 5.2 & 4.7 & 4.1 & 3.3 \\
\hline & Transport fuels & 7.9 & 8.2 & 8.7 & 9.3 & 9.6 \\
\hline \multirow[t]{3}{*}{ Mexico } & Electricity & 4.1 & 3.5 & 2.9 & 2.7 & 2.0 \\
\hline & Gas & 7.4 & 5.6 & 4.7 & 3.9 & 2.7 \\
\hline & Transport fuels & 11.7 & 10.7 & 10.6 & 10.8 & 9.7 \\
\hline \multirow[t]{3}{*}{ Nicaragua } & Electricity & 3.4 & 3.8 & 3.7 & 3.7 & 3.7 \\
\hline & Gas & 6.5 & 5.0 & 4.1 & 3.3 & 2.2 \\
\hline & Transport fuels & 10.6 & 11.9 & 11.3 & 10.9 & 13.4 \\
\hline \multirow[t]{3}{*}{ Peru } & Electricity & 3.7 & 2.9 & 2.9 & 2.8 & 2.5 \\
\hline & Gas & 6.8 & 3.7 & 2.7 & 2.0 & 1.4 \\
\hline & Transport fuels & 5.4 & 3.6 & 3.3 & 3.5 & 4.3 \\
\hline
\end{tabular}


Table 3 (continued). Energy Budget Shares, by Total Household Expenditure Quintile (\%, excluding zero reported energy expenditures)

\begin{tabular}{llccccc}
\hline \multirow{3}{*}{ Country } & Fuel & \multicolumn{5}{c}{ Expenditure quintile, pc hh } \\
\cline { 3 - 7 } Paraguay & Electricity & 2.6 & 2.9 & 3.1 & 3.2 & 2.9 \\
& Gas & 2.6 & 2.3 & 1.9 & 1.8 & 1.3 \\
& Transport fuels & 4.3 & 4.3 & 4.9 & 5.2 & 6.5 \\
& & & & & & \\
\multirow{2}{*}{ Uruguay } & Electricity & 11.7 & 9.5 & 7.7 & 6.1 & 4.5 \\
& Gas & 6.5 & 4.8 & 3.6 & 2.8 & 1.7 \\
& Transport fuels & 7.1 & 6.6 & 6.0 & 6.0 & 6.3 \\
& & & & & & \\
Pooled & Electricity & 5.0 & 4.2 & 3.6 & 3.2 & 2.3 \\
Sample & Gas & 4.5 & 3.0 & 2.4 & 1.9 & 1.2 \\
& Transport fuels & 10.2 & 9.2 & 9.3 & 9.0 & 7.7 \\
\hline
\end{tabular}

Source: Own elaboration.

Note: Excludes zero reported energy expenditures. All values are weighted using the population expansion factor.

Table 4. Distribution of Fuels' Take-Up by Quintile (as percentage of total households within each quintile)

\begin{tabular}{lccc}
\hline Expenditure quintile, pc hh & Electricity & Dom. Gas & Transport Fuel \\
\hline Poorest & 84.8 & 70.9 & 12.9 \\
Q2 & 88.2 & 80.2 & 20.6 \\
Q3 & 90.2 & 82.9 & 27.5 \\
Q4 & 92.2 & 83.3 & 36.7 \\
Richest & 94.8 & 79.3 & 53.1 \\
Total & 89.9 & 79.3 & 29.8 \\
\hline
\end{tabular}

Source: Own elaboration.

Note: Includes zero reported energy expenditures. Values are weighted using the population expansion factor.

In addition to the heterogeneity across countries and income groups, there is also considerable variation within each quintile. That is, not only do energy expenditures tend to have a higher weight in lower-income households; they also have a significantly more skewed distribution of energy share. Following Advani et al. (2013), this variation can be observed through a box plot. Figure 3 shows the pronounced variation in energy expenditure shares across income groups, with the distribution depicted from the 10th percentile (bottom whisker) to the 90th percentile (top whisker). The box plots are bounded by the lower quartile (bottom) and upper quartile (top), and the median is depicted by the box's central line. The variability is greater for the poorest quintile, where one in ten households spends more than 15 percent of its budget on energy, while more than one in ten report zero energy spending. By contrast, 50 percent of all households in the top quintile present an energy share in the narrower range from 1.4 to 4 percent.

It is also useful to know how the aggregate energy expenditure distribution by income and fuel. Table 5 shows that the 20 percent richest concentrate more than 40 percent of total expenditures on energy, while the bottom 20 percent poorest concentrate around 7 percent. Transport fuels constitute the bulk of the energy basket in the richest group. Around 65 percent of total energy expenditures in the fifth quintile go toward private transportation. In contrast, expenditures on domestic energy sources make up the largest share of energy expenditures in the poorest income group, at 80 percent. This aggregate view depicts the distributive characteristics of energy expenditures. While the poorest households are the most vulnerable to price shocks giv- 
en the energy share in their expenditure, their share of national energy expenditures is less than one-sixth of the highest quintile. This pattern is clearest in the case of fuels for private transportation, where the poorest households account for less than 2 percent of aggregate expenditures on transport fuels, while the richest quintile represents around one-third. In this sample, we do not observe such remarkable differences among quintiles for domestic gas.

Figure 3. Household Energy Spending by Expenditure Decile

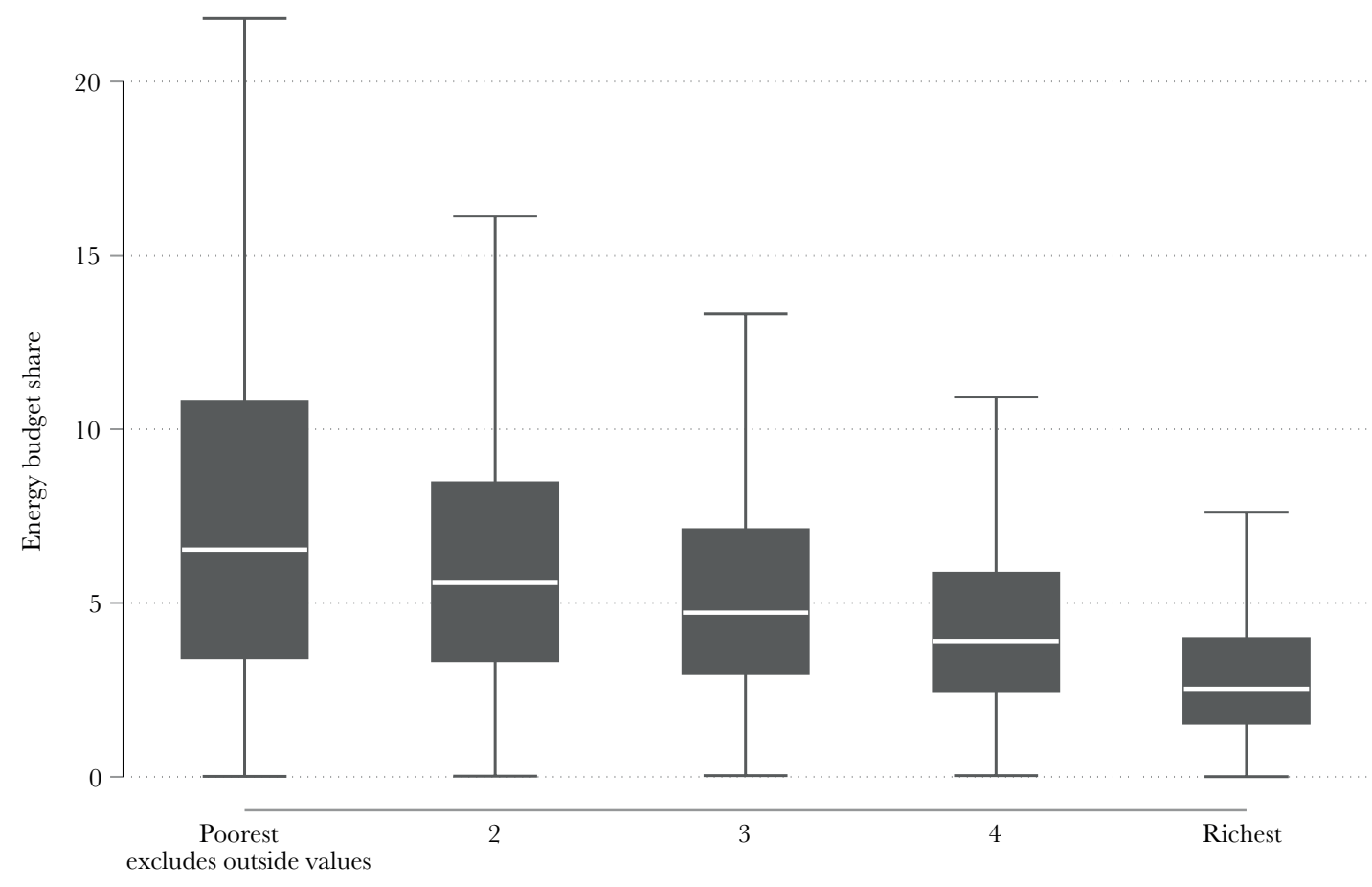

Source: Own elaboration.

Note: The figure does not include outside values. Values are weighted using the population expansion factor.

Table 5. Distribution of Aggregate Energy Expenditures by Quintile and Fuel (as a percentage of total energy expenditure)

\begin{tabular}{lcccc}
\hline Expenditure quintile, pc hh & All fuels & Electricity & Dom. Gas & Transport Fuel \\
\hline Poorest & 6.8 & 3.3 & 2.3 & 1.2 \\
Q2 & 11.5 & 5.2 & 3.1 & 3.2 \\
Q3 & 16.1 & 6.5 & 3.3 & 6.3 \\
Q4 & 23.7 & 8.1 & 3.5 & 12.1 \\
Richest & 42.0 & 11.1 & 3.8 & 27.2 \\
Total & 100.0 & 34.3 & 15.9 & 49.8 \\
\hline
\end{tabular}

Source: Own elaboration.

Note: Includes zero reported energy expenditures. Values are weighted using the population expansion factor.

\section{Empirical Approach}

This section presents the approach to investigate the determinants of energy expenditure. Following a stream of empirical work (e.g., Foster et al., 2000; Meier et al., 2013; Longhi, 2015; Martins et al., 2016), we propose a set of equations following a common unrestricted specification for all fuels: 


$$
\ln E_{h}=\ln f\left(Y_{h}, \alpha\right)+\beta X_{h}+I_{l h}+\varepsilon_{h}
$$

where $E_{h}$ represents the spending and budget shares of household $h$ on each specific energy source (i.e., electricity, domestic gas, and transport fuels). $f\left(Y_{h}, \alpha\right)$ represents a functional form of income $(Y)$, which allows us to use different specifications of interest. Energy expenditure and income are expressed in natural logarithms. For the baseline regressions, $f\left(Y_{h}, \alpha\right)$ takes a linear form, $\alpha \ln \left(Y_{h}\right)$, and the estimated $\alpha$ represents the average income elasticity. Consistent with the literature, it is expected to have a positive sign and be less than unity. Although this linear specification provides an overall view of the energy-income association, it is restrictive to assume that this relationship does not change along the income distribution.

Therefore, to examine the correlation between energy expenditures and income, we specify the income function as a polynomial. In the literature, $f(\cdot)$ is specified as first-, second-, and third-order functions (Banks et al., 1997; Meier et al., 2013). We test these specifications and compare their performances to find the most suitable functional form for each energy source. ${ }^{7}$ This is an important distinction, as the relationship between energy expenditures and income may depend on the actual energy type. In the cases of electricity and gas, the best fits were found to be a third- and second-degree polynomial, respectively. For transport fuels, the best fit was third degree for spending and second degree for budget share. See $\underline{\text { Annex B }}$ for the regression details.

An advantage of using a polynomial function is that it allows estimating the elasticity at different points of the income distribution. For example, the elasticity corresponding to the third-degree polynomial takes the form $\varepsilon_{E, Y}=\alpha_{1}+2 \alpha_{2} \ln Y_{h}+3 \alpha_{3} \ln Y_{h}{ }^{2}$. However, the expected signs of the estimated coefficients are less clear, and the focus is on approximating the behavior of energy expenditure along the income range, being a matter of empirical debate. Meier et al. (2013) find that energy spending elasticities increase nonlinearly with income. In contrast, for the case of energy consumption, Foster et al. (2000) (at the household level) and Jimenez et al. (2018) (at the country level) find evidence of an inverse U-shaped relationship, in the sense that energy consumption tends to stabilize, and even reduce, at higher income levels.

For the set of covariates $\left(X_{h}\right)$ that may affect energy expenditure, we include family age and size composition, urban/rural geographic area, dwelling size, appliances (TV, refrigerator, and computer), vehicle ownership, and ownership of the dwelling. In the case of food expenditures, Benus et al. (1976) evaluate the EOS of family age and size composition by distinguishing the number of members per age group within the household, and adding their squares. The first coefficient is expected to be positive, since expenditures typically increase with family size. The coefficient of the squared variable is interpreted as the direction of the EOS for each cohort. Following this approach, we divide each family in two cohorts (number of household members younger than 12 years, and number older than 12 years) and their corresponding squares. To evaluate EOS with respect to dwelling size, we extend this logic by including the square of the number of rooms in the dwelling.

In this exercise, we do not have information on the energy prices paid by end-users. Such information is only available at the country aggregated level, so including those average prices would only capture cross-country variations and could be a noisy measure since prices may differ significantly within countries. Indeed, price variation occurs because most energy pricing mechanisms consider consumption bands and household location settings, among other factors, thereby leading to heterogeneity in final tariffs across households. This is a context in which average national energy prices are not very informative, especially when they come from cross-sectional data. ${ }^{8}$ To reduce this problem, we take advantage of the detailed geo-

$7 \quad$ We compare their information criteria statistics and adjusted R-squared.

8 Including country-average price data here may lead to significant measurement error (me) and, thus, biased estimates. That is, if $m e$ is correlated with income or other household characteristics, it will bias all the estimated parameters $(\hat{\alpha}, \hat{\beta})$. The location parameter, among others, may capture the effect of prices, in which case we would not be able to identify the price effects. 
graphical information provided in the surveys. This information is translated into two location indicators; one accounting for the most finer geographical household location available in the survey $\left(I_{h}\right)$, which, depending on the survey, may represent a municipality or village, and second more aggregated location dummy that can represent province, department or region $\left(f_{h}\right)$. The analysis accounts for more than $3,500 I_{h}$ and $940 f_{h}$, to capture differences in energy prices faced by households living within the same area, as well as other location-specific effects, such as temperature and the reliability of energy services. Importantly, these variables also capture country-specific characteristics, such electricity tariffs structures, or natural resource abundance (which may affect energy costs), as well as, difference in economic shocks affecting differently to each location, and therefore country, in the sample.

However, the location indicator may not completely allow us to identify differences in energy prices paid by end-users within a given area. In the case of electricity, incremental block pricing may bias the estimation of the income coefficient, since income and electricity consumption tend to be positively correlated (e.g. Borenstein, 2012). Further, in countries such as Mexico and Peru, electricity tariffs -in addition to being defined by band of electricity consumption- also depend on socioeconomic characteristics of geographical areas, such that tariffs tend to be lower in relatively poorer areas. Prices for domestic gas and transport fuels may also present spatial variability for different reasons. Prices may vary reflecting price-skimming strategies of the suppliers, or due to differences in the complementary services provided along with the fuels or by subsidies. In both cases, typically wealthier household tend to face higher prices. For example, in El Salvador and Peru, GLP for domestic use tend to be subsidized for low income households. On the other hand, these prices can vary because of transactional costs, being expected that rural areas tend to face higher energy prices, though such prices variation can be expected to be absorbed for the location indicators.

Meier et al. (2013) argue that those differences can be interpreted as measurement error. The authors use average annual prices and a proxy variable to control for systematic deviations using the following decomposition of the price vector:

$$
\ln P_{h}=\ln P_{t}+\ln \left(\frac{P_{h}}{P_{L}}\right)+\ln \left(\frac{P_{L}}{P_{t}}\right)
$$

where $P_{h}$ is the actual price paid by the household, $P_{L}$ is the price common to the location or area of a given household, and $P_{t}$ is the average annual price. Following this strategy, we can include the price vector in our previous specification (equation 1) and rewrite it as follows:

$$
\ln E_{h}=\ln f\left(Y_{h}, \alpha\right)+\beta X_{h}+\gamma \ln P_{t}+\gamma\left[\ln \left(\frac{P_{h}}{P_{L}}\right)+\ln \left(\frac{P_{L}}{P_{t}}\right)\right]+f_{h}+\varepsilon_{h}
$$

The terms in brackets represent the measurement error. As those terms are not available, Meier et al. (2013) use income differences as a proxy. That is, they replace $P_{\mathrm{h}}$ by the household income per capita $\left(Y_{h p c}\right)$ and $P_{L}$ by average household income per capita within a geographical area $\left(Y_{I p c}\right)$. The incomes and their averages by location are calculated from the surveys in each country at the $I_{h}$ level. In our cross-sectional setting, average energy prices $\left(\ln P_{t}\right)$ and geographical differences in energy prices $\left(\ln \left(\frac{\mathrm{P}_{\mathrm{L}}}{\mathrm{P}_{\mathrm{t}}}\right)\right.$ will be absorbed by the location fixed effects, $f_{h}$, whilethe actual price paid by the household $\left(P_{h}\right)$ provides variation within each location. Notice, this replacement takes advantage of the typical incremental pricing observed for higher levels of energy consumption and for wealthier households (i.e. higher tariffs are expected to be more positively correlated with household per capita income than with overall household income). ${ }^{9}$

9 It is important to mention that, in the case of electricity it is well-documented that block pricing can have significant filtration of high-income households in subsidized tariff for low electricity consumption. See Hancevic \& Lopez-Aguilar (2019) for the case of Mexico, Navajas (2013) for Nicaragua and Marchioni et al. (2008) for Argentina. Nonetheless, we think that using this correction is better than omitting a potentially informative proxy. In fact, our results seem to support the used of this ratio as a proxy for pricing. As a robustness check, Annex D presents the main energy regression without the correction term. The exclusion of the correction term affects mainly the income coefficient. In the case of the energy 
Therefore, we are left to correct the difference in energy prices within each geographic location, such that the final specification is

$$
\ln E_{\mathrm{h}}=\ln f\left(Y_{\mathrm{h}}, \alpha\right)+\beta \mathrm{X}_{\mathrm{h}}+\gamma \ln \left(\frac{\mathrm{Y}_{\mathrm{hpc}}}{\mathrm{Y}_{\mathrm{Ipc}}}\right)+f_{\mathrm{h}}+\varepsilon_{\mathrm{h}}
$$

where $\ln \left(\frac{Y_{\text {hpc }}}{Y_{\text {Ipc }}}\right)$ is the proxy for different prices faced by households within their location (i.e., $\left.I_{h}\right)$. We call this correction term "ywithin." This correction term is not of primary interest in our analysis; rather, it is mainly used in an attempt to clear up the omitted variable problem in the estimations. For higher values of ywithin (proxying higher prices faced by the end-user) we could expect lower energy consumption. Although its impact on spending and budget share will depend on the extent of the response of the energy demand, we can expect that it will not be absorbed by the income coefficient (since energy prices can be positively correlated with income as previously commented).

It is important to emphasize that we interpret the estimations as conditional correlations. That is, although we expect that the inclusion of the covariates and fixed effects helps to clean up the estimates, they may still be subject to different sources of bias, namely: measurement error of income, sample selection, functional form misspecification, and simultaneity bias between energy expenditure and household income. Nonetheless, in the following, we discuss the implications of these potential problems and how we expect to mitigate them.

Regarding measurement error, one of the main concerns in our context is with household income, as it is known to be highly subject to misreporting, potentially leading to attenuation bias. Therefore, following Kay et al. (1984) and Pudney \& Francavilla (2006), instead of income, we use total household expenditure as a more reliable measure of household economic welfare.

Sample selection may appear if households systematically misreport information. For example, the dependent variable may be zero for three possible reasons: (i) non-consumption, (ii) no recall of information, and (iii) omitted response during the survey. Since we are focusing the analysis on households with positive consumption, the main concern is that (ii) and (iii) occur in a way that is correlated with the main independent variable; income. This situation would lead to inconsistently estimated relationships and, therefore, a lack of external validity due to the censored nature of the data. We assume not systematic misreporting, which is a common implicit practice in several applications ( $\underline{\text { Foster et al., 2000; }}$ Meier et al., 2013). ${ }^{10}$

Functional form misspecification implies that our average estimate may not be representative of the overall relationship, for example, if such link is pronouncedly nonlinear. We expect that the proposed polynomial specifications -for income, family age composition, and dwelling size- will reduce this problem.

The main concern to avoid attributing a causal interpretation to the estimates is the potential existence of simultaneity bias. On the one hand, according to economic theory, household expenditure decisions are jointly determined, and household income is the result of a utility maximization problem, that is household income respond to the optimal setting of expenditure budget accounts. On the other hand, although the focus is on the effect of income changes on

spending regressions, excluding this term, reduce the income coefficient as it would be expected from omitting prices in the regression. That is, the new estimates seem to be confounding the omission of prices in the regression (negative price coefficient) and absorbing then into the new estimates. Similarly, in the energy budget share regressions, the estimated income coefficients are larger potentially indicating that such estimates are also confounding the corresponding price coefficients (which are positive for necessity services). Overall, the inclusion of the price proxy correction seems to help obtaining more clean estimates of the income marginal effect.

10 Under (ii) and (iii), expenditure becomes a latent variable. The usual approach to deal with this type of endogeneity is to identify appropriate instrumental variables to account for the probability of self-selection in the sample. This requires identify non-consumption from access to a given fuel, which is particularly problematic in the case of domestic gas. (See Nicoletti \& Peracchi, 2005, and De Luca \& Peracchi, 2011, for a discussion of estimation issues of Engel expenditure curves.) 
energy spending, it may also be the case that energy spending would, in turn, affect income in a more indirect way. As energy expenditure increases, it generally would represent higher energy use, which may signify a more productive use of time within the dwelling - i.e., better conditions for studying or developing other productive activities. Such a more productive use of time would translate into higher incomes and therefore greater energy expenditures. Therefore, it is important to have into account that if the feed-back from energy to income is positive, our results would be upward-biased.

All regressions are performed using the robust covariance matrix to account for potential heteroscedasticity. This particularly relevant as there are many explanatory variables which are correlated with income, such as dwelling size, ownership of electric equipment, etc. Notice, however, that it will not reduce the predictive power of reliability of our models. Further, our application benefits from a large dataset making the issue of larger standard errors less problematic. Also, as per to account for the large data used the analysis, we have set more stringent p-values to address statistical significance (or relevant standard errors/confidence intervals), i.e., $5 \%, 1 \%$, and $0.1 \%$.

\section{Results}

This section presents the main results of the strategies previously described. First, we present the average estimates of the energy regressions. For comparison purposes, Panels A and B present the unconditional and conditional income coefficient, respectively. Subsections 5.2 to 5.3 expand the empirical analysis by estimating the corresponding conditional Engel curves and the income elasticities at different points of the income distribution.

\subsection{Determinants of Energy Expenditure}

Tables 6 and 7 summarize the results of regressing equation 4 for energy spending and energy share of total household expenditure, respectively. The relationship between energy expenditure/share and income is assumed to be linear. Then, the returned coefficient represents the average income elasticity of energy expenditure/share for the pooled sample.

Overall, the unconditional income elasticity is greater than the conditional estimates, except for the case of share spending on transport fuels (where confidence intervals overlap). The results indicate that household characteristics play a significant role and operate in an expected fashion in determining energy spending, although with relevant distinctions between fuels. The conditional estimates provide information independent of household heterogeneity (i.e., demographic characteristics and household energy-intensive equipment ownership), therefore approximating the marginal effect of income. ${ }^{11}$ This estimate is also informative with respect of the role income at driven energy consumption/expenditure at the intensive-margin. With respect to energy expenditures (Table 6), the highest sensitivity to an income change is given for transport fuels (0.65 elasticity), followed by electricity (0.41) and domestic gas (0.18). However, although spending on transport fuel increases the most with income, the energy share estimates (Table 7) indicate that its budget weight decreases. That is, on average, expenditure on all fuels increases at a lower rate than income does.

For family age composition, the results strongly suggest the prevalence of EOS with respect to domestic energy (i.e., electricity and domestic gas). For those fuels, all first-degree terms relating to the age distribution of the family -number of children and number of household members older than 12- are positive, indicating that greater household size tends to be associated with higher energy expenditures, as well as higher energy share. All the quadratic terms have a neg-

11 For example, Baker et al. (1989) show different income elasticities for households with different demographics in the United Kingdom, and Nicoletti \& Peracchi (2005) show substantial heterogeneity in the Engel curves for food. 
ative sign, reflecting the realization of EOS in energy expenditures. The fact that the quadratic terms are negative and statistically significant in the energy share regression indicates that those EOS are quite relevant for the structure of household budgets. In contrast, expenditure on and share of transport fuels appear not to be systematically correlated with household age composition, but mainly with income, area of living and motor-vehicle ownership. ${ }^{12}$ Overall, these findings are consistent with those of Ironmonger et al. (1995) and Underwood \& Zahran (2015), who suggest that the global trend toward smaller family size may offset the potential gains in energy efficiency.

Table 6. Energy Expenditure Regressions, Pooled Sample

\begin{tabular}{|c|c|c|c|c|}
\hline & \multicolumn{4}{|c|}{ Dependent: $\operatorname{Ln}($ expenditure in..) } \\
\hline & All (1) & Electricity (2) & Gas (3) & $\begin{array}{l}\text { Transport } \\
\text { fuels (4) }\end{array}$ \\
\hline \multicolumn{5}{|c|}{ Panel A: Unconditional Income Coefficient } \\
\hline \multirow[t]{2}{*}{ Ln(household expenditure) } & $0.921 * * *$ & $0.707 * * *$ & $0.082^{* * * *}$ & $0.740 * * *$ \\
\hline & $(0.005)$ & $(0.004)$ & $(0.004)$ & $(0.007)$ \\
\hline \multicolumn{5}{|l|}{ Panel B: Full Regression } \\
\hline \multirow[t]{2}{*}{ Ln(household expenditure) } & $0.638 * * *$ & $0.413^{* * *}$ & $0.177 * * *$ & $0.648 * * *$ \\
\hline & $(0.011)$ & $(0.011)$ & $(0.010)$ & $(0.020)$ \\
\hline \multirow[t]{2}{*}{ Urban $=1$, Rural $=0$} & $0.137 * * *$ & $0.250 * * *$ & $0.022^{* * * *}$ & $-0.070 * * *$ \\
\hline & $(0.008)$ & $(0.009)$ & $(0.006)$ & $(0.014)$ \\
\hline \multirow[t]{2}{*}{ Number of children } & -0.005 & $0.030 * * *$ & $0.045^{* * *}$ & $-0.043^{* * * *}$ \\
\hline & $(0.007)$ & $(0.007)$ & $(0.006)$ & $(0.012)$ \\
\hline \multirow[t]{2}{*}{ Number of children squared } & $-0.004^{*}$ & $-0.007 * * *$ & $-0.004 *$ & $0.006^{*}$ \\
\hline & $(0.002)$ & $(0.002)$ & $(0.002)$ & $(0.003)$ \\
\hline \multirow{2}{*}{$\begin{array}{l}\text { Number of hh members } \\
\text { older than } 12\end{array}$} & $0.089 * * *$ & $0.106^{* * *}$ & $0.138^{* * *}$ & -0.030 \\
\hline & $(0.010)$ & $(0.010)$ & $(0.008)$ & $(0.018)$ \\
\hline \multirow{2}{*}{$\begin{array}{l}\text { Number of hh members } \\
\text { older than } 12, \text { squared }\end{array}$} & $-0.011 * * *$ & $-0.010^{* * *}$ & $-0.012 * * *$ & -0.001 \\
\hline & $(0.001)$ & $(0.001)$ & $(0.001)$ & $(0.002)$ \\
\hline \multirow{2}{*}{$\begin{array}{l}\text { Number of rooms in the } \\
\text { dwelling }\end{array}$} & $0.082^{* * * *}$ & $0.055^{* * *}$ & $0.021 * * *$ & $0.026^{* * * *}$ \\
\hline & $(0.005)$ & $(0.004)$ & $(0.003)$ & $(0.007)$ \\
\hline \multirow{2}{*}{$\begin{array}{l}\text { Number of rooms in the } \\
\text { dwelling, squared }\end{array}$} & $-0.003^{* * *}$ & $-0.001^{* *}$ & $-0.000 *$ & $-0.001 * *$ \\
\hline & $(0.000)$ & $(0.000)$ & $(0.000)$ & $(0.000)$ \\
\hline
\end{tabular}

12 In the case of transport, education and size of the dwelling are also significant in the energy spending regression. While those result do not always maintain for the energy share regressions, they may be capturing some income effect. 
Table 6 (continued). Energy Expenditure Regressions, Pooled Sample

\begin{tabular}{|c|c|c|c|c|}
\hline & \multicolumn{4}{|c|}{ Dependent: $\operatorname{Ln}$ (expenditure in..) } \\
\hline & All (1) & Electricity (2) & Gas (3) & $\begin{array}{l}\text { Transport } \\
\text { fuels (4) }\end{array}$ \\
\hline \multirow[t]{2}{*}{ Ownership of a refrigerator } & $0.312^{* * *}$ & $0.369^{* * *}$ & $0.046^{* * * *}$ & -0.006 \\
\hline & $(0.011)$ & $(0.012)$ & $(0.008)$ & $(0.020)$ \\
\hline \multirow[t]{2}{*}{ Ownership of a computer } & $0.075^{* * *}$ & $0.168^{* * * *}$ & $-0.020 * *$ & 0.005 \\
\hline & $(0.009)$ & $(0.009)$ & $(0.007)$ & $(0.013)$ \\
\hline \multirow[t]{2}{*}{ Ownership of a TV } & $0.150^{* * *}$ & $0.129 * * *$ & 0.003 & -0.013 \\
\hline & $(0.013)$ & $(0.013)$ & $(0.010)$ & $(0.025)$ \\
\hline \multirow[t]{2}{*}{ Ownership of an automobile } & $0.679 * * *$ & $0.083^{* * *}$ & -0.004 & $0.340^{* * *}$ \\
\hline & $(0.009)$ & $(0.009)$ & $(0.007)$ & $(0.013)$ \\
\hline \multirow[t]{2}{*}{ Ownership of the dwelling } & $0.058 * * *$ & 0.009 & $0.019 * *$ & 0.004 \\
\hline & $(0.008)$ & $(0.008)$ & $(0.006)$ & $(0.013)$ \\
\hline \multirow[t]{2}{*}{ ywithin } & $-0.103^{* * * *}$ & $-0.121^{* * *}$ & $-0.063^{* * *}$ & -0.015 \\
\hline & $(0.009)$ & $(0.009)$ & $(0.008)$ & $(0.018)$ \\
\hline \multirow{2}{*}{$\begin{array}{l}\text { Education level of the hh } \\
\text { head }\end{array}$} & $0.033^{* * *}$ & $0.030^{* * *}$ & -0.005 & $0.020^{* * *}$ \\
\hline & $(0.003)$ & $(0.003)$ & $(0.003)$ & $(0.005)$ \\
\hline \multirow[t]{2}{*}{ Age of the hh head } & $0.003^{* * * *}$ & $0.004^{* * *}$ & $0.004^{* * *}$ & $0.001^{* *}$ \\
\hline & $(0.000)$ & $(0.000)$ & $(0.000)$ & $(0.000)$ \\
\hline \multirow{2}{*}{$\begin{array}{l}\text { Gender of hh head }(\text { male }=1 \text {, } \\
\text { female }=0 \text { ) }\end{array}$} & $0.066^{* * * *}$ & $-0.031^{* * *}$ & -0.004 & $0.099^{* * * *}$ \\
\hline & $(0.007)$ & $(0.007)$ & $(0.006)$ & $(0.014)$ \\
\hline Observations & 182,851 & 164,468 & 144,978 & 54,487 \\
\hline Adjusted R-squared & 0.619 & 0.565 & 0.476 & 0.505 \\
\hline
\end{tabular}

Source: Own elaboration.

Note: Robust standard errors in parentheses. Estimations based on households with positive reported energy expenditures. Regressions are weighted by the population expansion factor. Statistical significance at $*<0.05$, $* *<0.01$, and $* * *<0.001$. All regressions contain household location dummies.

Table 7. Energy Budget Share Regressions, Pooled Sample

\begin{tabular}{lllll}
\hline \multicolumn{5}{c}{ Dependent: Ln(expenditure in..) } \\
\hline All (1) & Electricity (2) & Gas (3) & $\begin{array}{c}\text { Transport } \\
\text { fuels (4) }\end{array}$ \\
\hline Panel A: Unconditional Income Coefficient & & & \\
Ln(household expenditure) & $-0.894^{* * * *}$ & $-1.165^{* * *}$ & $-2.131^{* * *}$ & $-2.241^{* * *}$ \\
& $(0.036)$ & $(0.019)$ & $(0.022)$ & $(0.061)$ \\
\hline
\end{tabular}


Table 7 (continued). Energy Budget Share Regressions, Pooled Sample

\begin{tabular}{|c|c|c|c|c|}
\hline & \multicolumn{4}{|c|}{ Dependent: $\operatorname{Ln}($ expenditure in..) } \\
\hline & All (1) & Electricity (2) & Gas (3) & $\begin{array}{c}\text { Transport } \\
\text { fuels (4) }\end{array}$ \\
\hline \multicolumn{5}{|l|}{ Panel B: Full Regression } \\
\hline \multirow[t]{2}{*}{ Ln(household expenditure) } & $-2.845^{* * *}$ & $-2.153^{* * * *}$ & $-1.957 * * *$ & $-2.701 * * *$ \\
\hline & $(0.088)$ & $(0.047)$ & $(0.034)$ & $(0.172)$ \\
\hline \multirow[t]{2}{*}{ Urban $=1$, Rural $=0$} & $0.360 * * *$ & $0.704 * * *$ & $0.130 * * *$ & $-0.734^{* * *}$ \\
\hline & $(0.073)$ & $(0.038)$ & $(0.026)$ & $(0.140)$ \\
\hline \multirow[t]{2}{*}{ Number of children } & $-0.161^{* *}$ & 0.043 & -0.017 & $-0.359 * * *$ \\
\hline & $(0.060)$ & $(0.035)$ & $(0.019)$ & $(0.106)$ \\
\hline \multirow[t]{2}{*}{ Number of children squared } & 0.010 & -0.005 & 0.009 & 0.047 \\
\hline & $(0.014)$ & $(0.010)$ & $(0.005)$ & $(0.025)$ \\
\hline \multirow{2}{*}{$\begin{array}{l}\text { Number of hh members } \\
\text { older than } 12\end{array}$} & $0.412^{* * * *}$ & $0.248 * * *$ & $0.081 * *$ & $-0.393^{* *}$ \\
\hline & $(0.073)$ & $(0.035)$ & $(0.026)$ & $(0.151)$ \\
\hline \multirow{2}{*}{$\begin{array}{l}\text { Number of hh members } \\
\text { older than } 12 \text {, squared }\end{array}$} & $-0.053 * * *$ & $-0.020 * * *$ & $-0.012 * * *$ & 0.017 \\
\hline & $(0.008)$ & $(0.004)$ & $(0.003)$ & $(0.018)$ \\
\hline \multirow{2}{*}{$\begin{array}{l}\text { Number of rooms in the } \\
\text { dwelling }\end{array}$} & $0.569 * * *$ & $0.187 * * *$ & 0.014 & $0.197 * *$ \\
\hline & $(0.037)$ & $(0.016)$ & $(0.015)$ & $(0.061)$ \\
\hline \multirow{2}{*}{$\begin{array}{l}\text { Number of rooms in the } \\
\text { dwelling, squared }\end{array}$} & $-0.025^{* * *}$ & $-0.004^{* * * *}$ & $0.006 * * *$ & $-0.009 *$ \\
\hline & $(0.002)$ & $(0.001)$ & $(0.001)$ & $(0.004)$ \\
\hline \multirow[t]{2}{*}{ Ownership of a refrigerator } & $1.677 * * * *$ & $1.004 * * *$ & 0.012 & 0.170 \\
\hline & $(0.082)$ & $(0.055)$ & $(0.035)$ & $(0.178)$ \\
\hline \multirow[t]{2}{*}{ Ownership of a computer } & $0.370^{* * * *}$ & $0.521^{* * *}$ & $0.186 * * * *$ & -0.115 \\
\hline & $(0.080)$ & $(0.033)$ & $(0.021)$ & $(0.122)$ \\
\hline \multirow[t]{2}{*}{ Ownership of a TV } & $0.777 * * *$ & $0.314 * * *$ & $-0.168^{* *}$ & -0.018 \\
\hline & $(0.104)$ & $(0.061)$ & $(0.053)$ & $(0.250)$ \\
\hline \multirow[t]{2}{*}{ Ownership of an automobile } & $5.483 * * *$ & $0.295 * * *$ & $0.295^{* * *}$ & $2.113^{* * * *}$ \\
\hline & $(0.087)$ & $(0.034)$ & $(0.023)$ & $(0.120)$ \\
\hline \multirow[t]{2}{*}{ Ownership of the dwelling } & $0.370^{* * * *}$ & -0.021 & 0.025 & -0.101 \\
\hline & $(0.064)$ & $(0.033)$ & $(0.020)$ & $(0.120)$ \\
\hline
\end{tabular}


Table 7 (continued). Energy Budget Share Regressions, Pooled Sample

\begin{tabular}{|c|c|c|c|c|}
\hline & \multicolumn{4}{|c|}{ Dependent: $\operatorname{Ln}$ (expenditure in..) } \\
\hline & All (1) & Electricity (2) & Gas (3) & $\begin{array}{l}\text { Transport } \\
\text { fuels (4) }\end{array}$ \\
\hline \multirow[t]{2}{*}{ ywithin } & $-0.521 * * *$ & $-0.347 * * *$ & $-0.189 * * *$ & -0.072 \\
\hline & $(0.075)$ & $(0.040)$ & $(0.024)$ & $(0.152)$ \\
\hline \multirow{2}{*}{$\begin{array}{l}\text { Education level of the hh } \\
\text { head }\end{array}$} & $0.210 * * *$ & $0.115^{* * *}$ & -0.009 & $0.111 * *$ \\
\hline & $(0.025)$ & $(0.011)$ & $(0.008)$ & $(0.039)$ \\
\hline \multirow[t]{2}{*}{ Age of the hh head } & $0.016^{* * *}$ & $0.014^{* * * *}$ & $0.015^{* * * *}$ & $0.014^{* * *}$ \\
\hline & $(0.002)$ & $(0.001)$ & $(0.001)$ & $(0.004)$ \\
\hline \multirow{2}{*}{$\begin{array}{l}\text { Gender of hh head }(\text { male }=1 \text {, } \\
\text { female }=0 \text { ) }\end{array}$} & $0.639 * * *$ & $-0.120 * * *$ & -0.034 & $0.717 * * *$ \\
\hline & $(0.058)$ & $(0.031)$ & $(0.021)$ & $(0.116)$ \\
\hline Observations & 182,851 & 164,468 & 144,978 & 54,487 \\
\hline Adjusted R-squared & 0.274 & 0.315 & 0.551 & 0.209 \\
\hline
\end{tabular}

Source: Own elaboration.

Note: Robust standard errors in parentheses. Estimations based on household with positive reported energy expenditures. Regressions are weighted by the population expansion factor. Statistical significance at $*<0.05$, $* *<0.01$, and $* * *<0.001$. All regressions contain household location dummies.

We also observe EOS with respect to dwelling size for electricity spending and its budget share. As expected, there is a positive association between the number of rooms in the dwelling, while the coefficient for the squared variable, although near zero, is statistically significant and has a negative sign. This suggests the presence of some energy savings with incremental dwelling size. In the case of domestic gas, the estimations are less clear, with EOS for expenditures but diseconomies of scale in budget share. With respect to transport fuel, as it is a priori expected, the results do not show an association with number of rooms.

A related question is whether these EOS differ between rich and poor. We evaluate this by interacting three income groups - first income group $=\operatorname{deciles} 1$ to 3 , second $=\operatorname{deciles} 4$ to 6 , and third $=$ deciles 7 to $10-$ with the variables family and dwelling size. Figure 4 presents the estimated marginal effects of electricity and gas expenditure. In the case of domestic gas, the intensity of EOS appears to be the same among the three income groups. In the case of electricity, the EOS of dwelling size also seems to behave in a similar way; however, the EOS of family size seems to be more pronounced for the richest group, emerging for families with more than six members.

The direction of the estimated coefficients for urban/rural location also depends on the specific fuel. Overall, urban households tend to spend more on and have a higher energy weight in their budgets (column 1 in Tables 6 and 7). This result seems to derive mainly from electricity expenditure, which represents an additional 0.70 percent of the budget for urban households, or 25 percent more annual expenditures (column 2 in Tables 6 and 7). The association with domestic gas is quite small. Families living in urban areas spend 2 percent more on domestic gas than those in rural areas (Table 6, column 3). In the budget share regression, the estimated coefficient indicates that the share of gas is 0.1 percent higher in urban areas (Table 7, column 3). 
Figure 4. Economies of Scale of Household Size and Dwelling Size, by Income Group
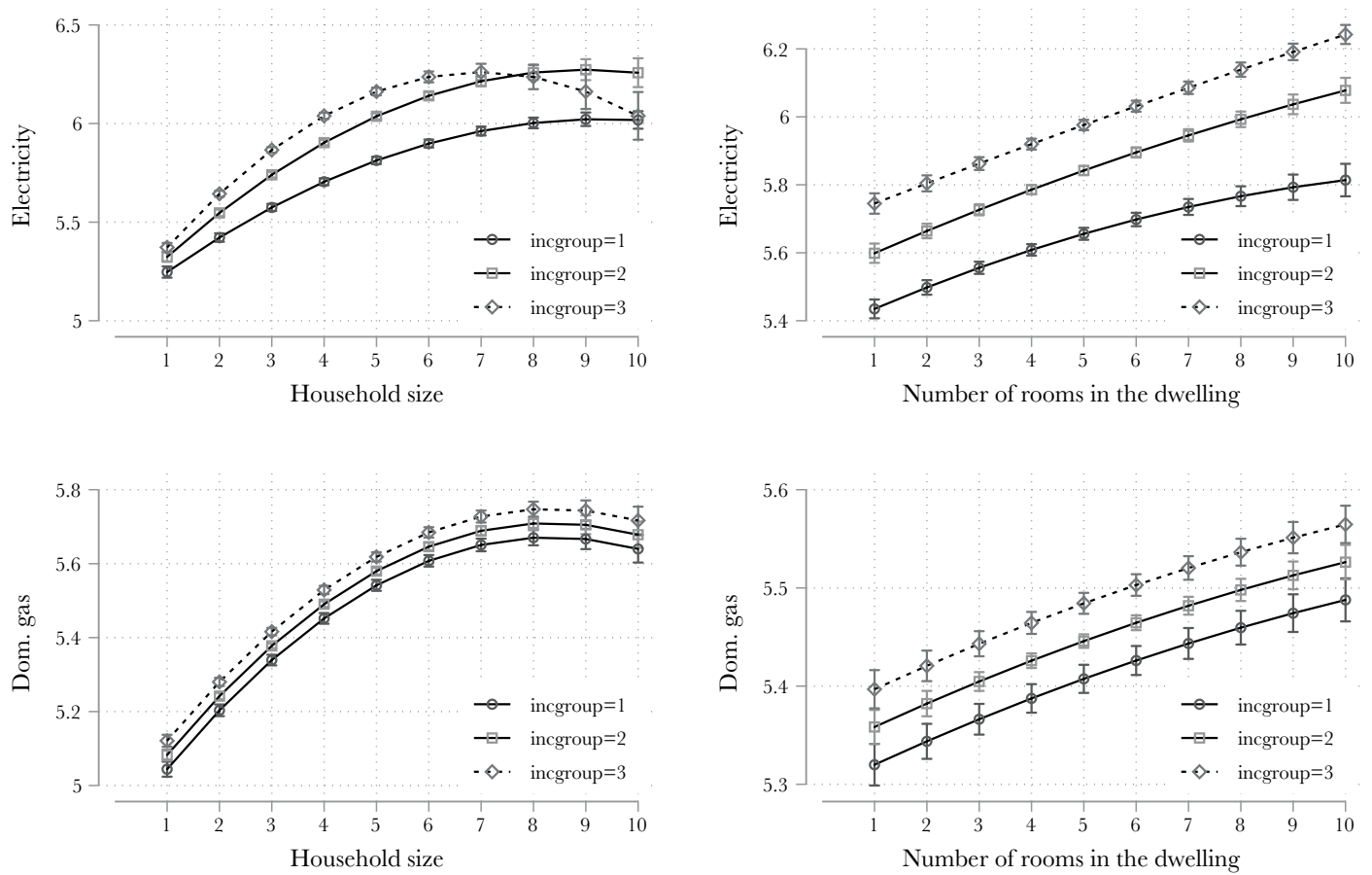

Source: Own elaboration.

Note: Incgroup $=1$ includes deciles 1 to $3 ;$ Incgroup $=2$ includes deciles 4 to $6 ;$ Incgroup $=3$ includes deciles 7 to 10 .

With respect to transport fuels, differences by urban/rural areas are also small. Compared with rural households, urban ones tend to spend 7 percent less on transport fuels, with an associated 0.7 percent lower share of their budget. Recall that these estimations are conditional on having positive energy expenditure. Unconditional estimates usually show that in urban areas liquid fuel expenditures tend to be higher because such computations include zero expenditures, of which urban households tend to have a lower proportion.

The ownership of appliances-refrigerators, computers, and TVs-is strongly correlated with higher electricity expenditure and the share of electricity in the household budget. Consistent with the extensively documented role of these appliances in increasing energy consumption, our estimations indicate that having a refrigerator, computer, and TV increases energy expenditure (and shares) by about 37 (1percent), 16.8 (0.52), and 12.9 percent (0.31), respectively. These estimates are greater than the marginal income effect. In the case of on domestic gas or transport fuels, as would be expected, having appliances is not systematically related to energy expenditures or shares.

As in Meier et al. (2013), the variable that is intended to capture measurement error in individual energy prices is statistically significant for all domestic fuels. That is, ywithin seems to work in capturing prices differentials within an area of residence, echoing higher prices faced by the end-users and having a negative effect on energy expenditures and energy budget shares. ${ }^{13}$ The results are not significant in the case of transport fuels, which may be explained because their prices tend to have lower spatial variability.

As an aside, to provide a glance at the heterogeneity in our estimations, we also perform the regression by each country in our sample. Overall, the findings prevail across countries. Table 8

13 Regressions without the ywithin term returns smaller income coefficient estimates, suggesting that, at least partially, this terms is capturing higher energy prices paid by relatively wealthier households. 
summarizes the income elasticities by country (Annex C reports the complete results). ${ }^{14}$ All the estimated income elasticities for energy expenditures are in the range $(0,1)$, reinforcing the intuition that in the household sector, all fuels - even for private transportation- could be considered necessity goods.

Table 8. Estimated Income Coefficient by Country

\begin{tabular}{|c|c|c|c|c|c|c|}
\hline \multirow[b]{2}{*}{ Country } & \multicolumn{3}{|c|}{ Expenditure on } & \multicolumn{3}{|c|}{ Budget Share of } \\
\hline & Electricity & Domestic gas & Transport fuels & Electricity & Domestic gas & Transport fuels \\
\hline \multirow{2}{*}{ Bolivia } & 0.396 & 0.108 & 0.577 & -1.045 & -0.764 & -1.035 \\
\hline & $(0.017)$ & $(0.014)$ & $(0.051)$ & $(0.049)$ & $(0.024)$ & $(0.247)$ \\
\hline \multirow{2}{*}{ Brazil } & 0.416 & 0.198 & 0.612 & -2.350 & -1.500 & -2.944 \\
\hline & $(0.021)$ & $(0.018)$ & $(0.036)$ & $(0.091)$ & $(0.039)$ & $(0.298)$ \\
\hline \multirow{2}{*}{ Costa Rica } & 0.390 & 0.014 & 0.606 & -1.606 & -0.899 & -3.156 \\
\hline & $(0.039)$ & $(0.073)$ & $(0.062)$ & $(0.123)$ & $(0.078)$ & $(0.491)$ \\
\hline \multirow{2}{*}{ Dom. Republic } & 0.738 & 0.249 & 0.711 & -0.737 & -2.525 & -1.780 \\
\hline & $(0.070)$ & $(0.042)$ & $(0.090)$ & $(0.311)$ & $(0.200)$ & $(0.775)$ \\
\hline \multirow{2}{*}{ Ecuador } & 0.499 & 0.059 & 0.615 & -0.854 & -0.493 & -1.262 \\
\hline & $(0.021)$ & $(0.010)$ & $(0.062)$ & $(0.051)$ & $(0.010)$ & $(0.246)$ \\
\hline \multirow{2}{*}{ Guatemala } & 0.411 & 0.198 & 0.593 & -2.950 & -2.987 & -2.941 \\
\hline & $(0.033)$ & $(0.028)$ & $(0.073)$ & $(0.244)$ & $(0.163)$ & $(0.637)$ \\
\hline \multirow{2}{*}{ Honduras } & 0.751 & 0.187 & 0.845 & -1.045 & -2.874 & -0.942 \\
\hline & $(0.053)$ & $(0.044)$ & $(0.089)$ & $(0.280)$ & $(0.225)$ & (1.128) \\
\hline \multirow{2}{*}{ Jamaica } & 0.350 & 0.152 & 0.685 & -5.860 & -4.255 & -3.709 \\
\hline & $(0.032)$ & $(0.027)$ & $(0.118)$ & $(0.435)$ & $(0.180)$ & $(0.974)$ \\
\hline \multirow{2}{*}{ Mexico } & 0.399 & 0.309 & 0.713 & -1.568 & -3.685 & -2.648 \\
\hline & (0.028) & $(0.031)$ & $(0.046)$ & $(0.113)$ & $(0.206)$ & $(0.494)$ \\
\hline \multirow{2}{*}{ Nicaragua } & 0.578 & 0.149 & 0.510 & -1.049 & -2.901 & -5.483 \\
\hline & $(0.067)$ & $(0.037)$ & $(0.134)$ & $(0.298)$ & $(0.159)$ & $(1.676)$ \\
\hline \multirow{2}{*}{ Peru } & 0.549 & 0.248 & 0.518 & -1.906 & -2.957 & -2.147 \\
\hline & $(0.018)$ & $(0.019)$ & $(0.060)$ & $(0.102)$ & $(0.116)$ & $(0.316)$ \\
\hline \multirow{2}{*}{ Paraguay } & 0.891 & 0.212 & 0.808 & -0.278 & -1.520 & -0.566 \\
\hline & $(0.064)$ & $(0.051)$ & $(0.073)$ & $(0.218)$ & $(0.121)$ & $(0.387)$ \\
\hline \multirow{2}{*}{ Uruguay } & 0.516 & 0.286 & 0.871 & -3.769 & -2.808 & -1.029 \\
\hline & $(0.031)$ & $(0.043)$ & $(0.076)$ & $(0.317)$ & $(0.226)$ & $(0.443)$ \\
\hline \multirow{2}{*}{ Pooled sample } & 0.413 & 0.177 & 0.648 & -2.153 & -1.957 & -2.70 \\
\hline & $(0.011)$ & $(0.010)$ & $(0.020)$ & $(0.047)$ & $(0.034)$ & $(0.172)$ \\
\hline
\end{tabular}

Source: by country regressions, see full result on $\underline{\text { Annex B }}$. Robust standard errors in parentheses

\subsection{Energy Engel Curves}

This subsection examines the shape of the relationship between energy expenditure/share and household income. For these estimations, in equation 4 , we specify $\ln f\left(Y_{h}, \alpha\right)$ with the best fit polynomial for each fuel (see Annex B), controlling for the same set of covariates as in the other regressions. Figure 5 presents the conditional predicted energy expenditures (panel A) and energy shares (panel B) along the income distribution of our sample. These curves are typically referred to as conditional Engel curves.

14 The results are also robust to the inclusion of different variables, such as the number of TVs and vehicles, for which information is available in a reduced sample of countries. 
The conditional predicted energy expenditure monotonically increases with income, shaping a linear relationship with a relatively tight 95 percent confidence interval (see Panel A). According to these estimations, greater differences are found in transport spending, as the corresponding Engel curve has a steeper slope than for electricity and gas. Although energy (absolute) expenditures increase with income, panel B shows that there is a large decrease in their budget weight as families become wealthier. That is, despite that poorer households have lower energy expenditures, they compromise a larger share of household income, implying pronounced affordability issues. Everything else constant, expenditure on electricity and gas at the lower income centile tend to represent between 16 and 12 percent of the household budgets. Further, the relatively tight 95 percent confidence interval, suggesting low heterogeneity across households within each income group.

We observe similar patterns for transport fuel, providing a complementary insight to those from Figure 2, where the share of transport fuels increases with income. Figure 2 shows unconditional averages by income group. In contrast, the estimated curves in Figure 5 represent the net correlation between energy expenditures/shares and household income conditional on positive expenditures and on all available covariates, offering a cleaner association between those variables. ${ }^{15}$ Therefore, this conditional Engel curve also indicate affordability issues by showing that a not small share of households have reveled preferences for spending on transport fuels even though it takes a substantial share of their income (and after accounting for household heterogeneity).

Figure 5. Conditional Energy Curves
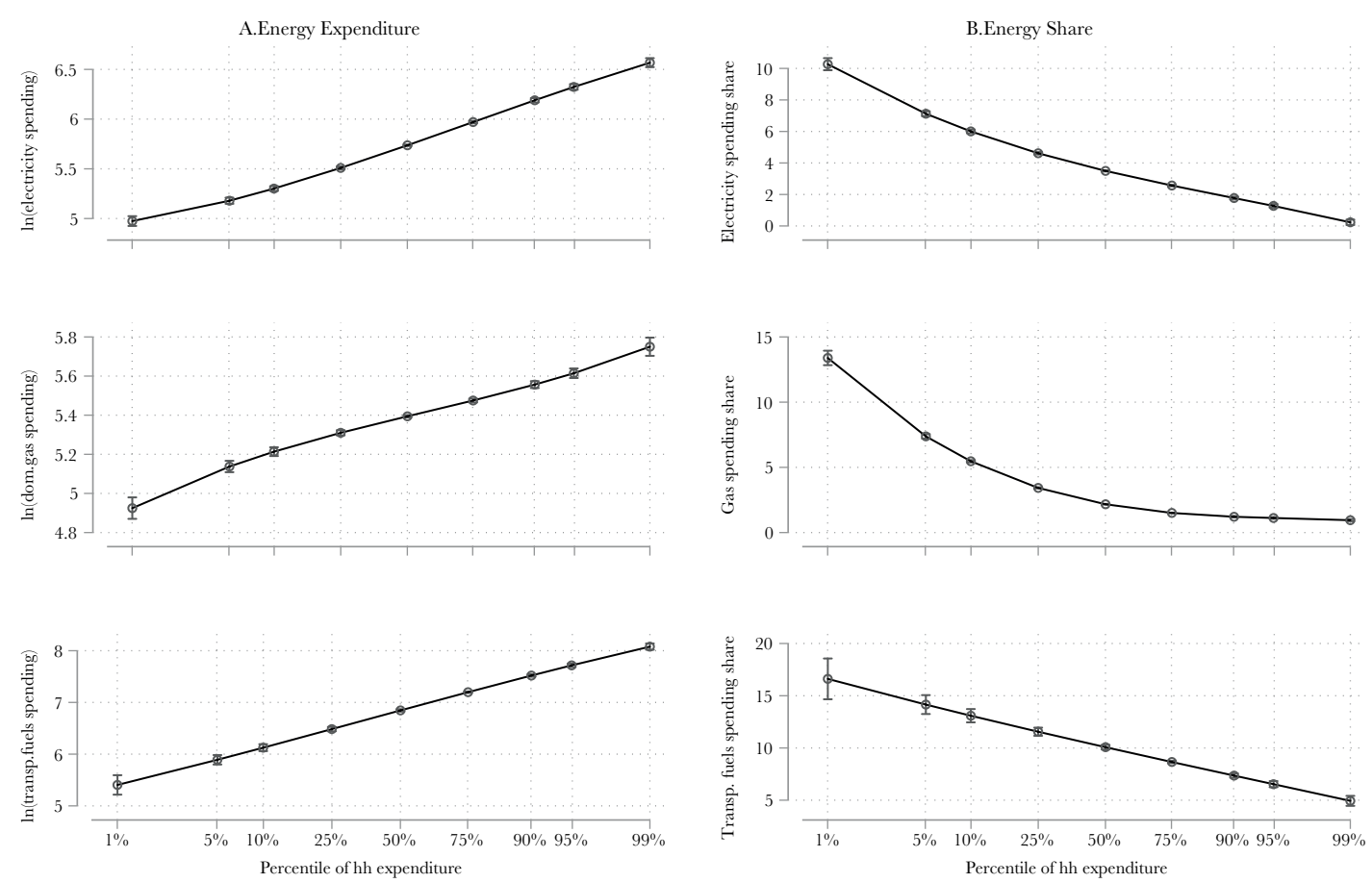

Source: Own elaboration.

Note: In panel A, the y-axis is energy expenditures on a natural logarithm scale. In panel B, the y-axis is energy expenditure as a percentage of the household budget.

\subsection{Estimated Income Elasticities along the Income Distribution}

Figure 6 plots the estimated income elasticities at different income percentiles. In line with previous results, these curves show that the elasticities remain positive and lower than unity for all

15 Differences between the conditional and unconditional transport fuel shares result from the significant heterogeneity in the values of the covariates between income groups. Our conditional estimates reflect the patterns for actual users of transport fuels (i.e., for those with positive expenditure). 
fuels over the entire income distribution. However, and in contrast to the energy Engel curves, the elasticities present markedly non-linear paths across fuels. For the case of electricity, its corresponding elasticity presents a concave shape, increasing from around 0.2 to around 0.45 , and then marginally reducing. That is, electricity expenditure grows at an incremental rate as income rises, up to a point where the rate of change stabilizes at a positive level. By contrast, the elasticity of domestic gas decreases towards the 50 percentile and increase onwards. The greatest variance is observed for transport fuels, for which the elasticity growths up to the 25th income percentile and then declines for richer segments. These estimates are consistent with those of Foster et al. (2000) and Jimenez et al. (2018), who find that the income elasticity of energy consumption tend to decrease to the right of the income distribution. These results may reflect a decreasing marginal utility in energy consumption and/or access to durable assets that are more energy-efficient.

Figure 6. Estimated Income Elasticities
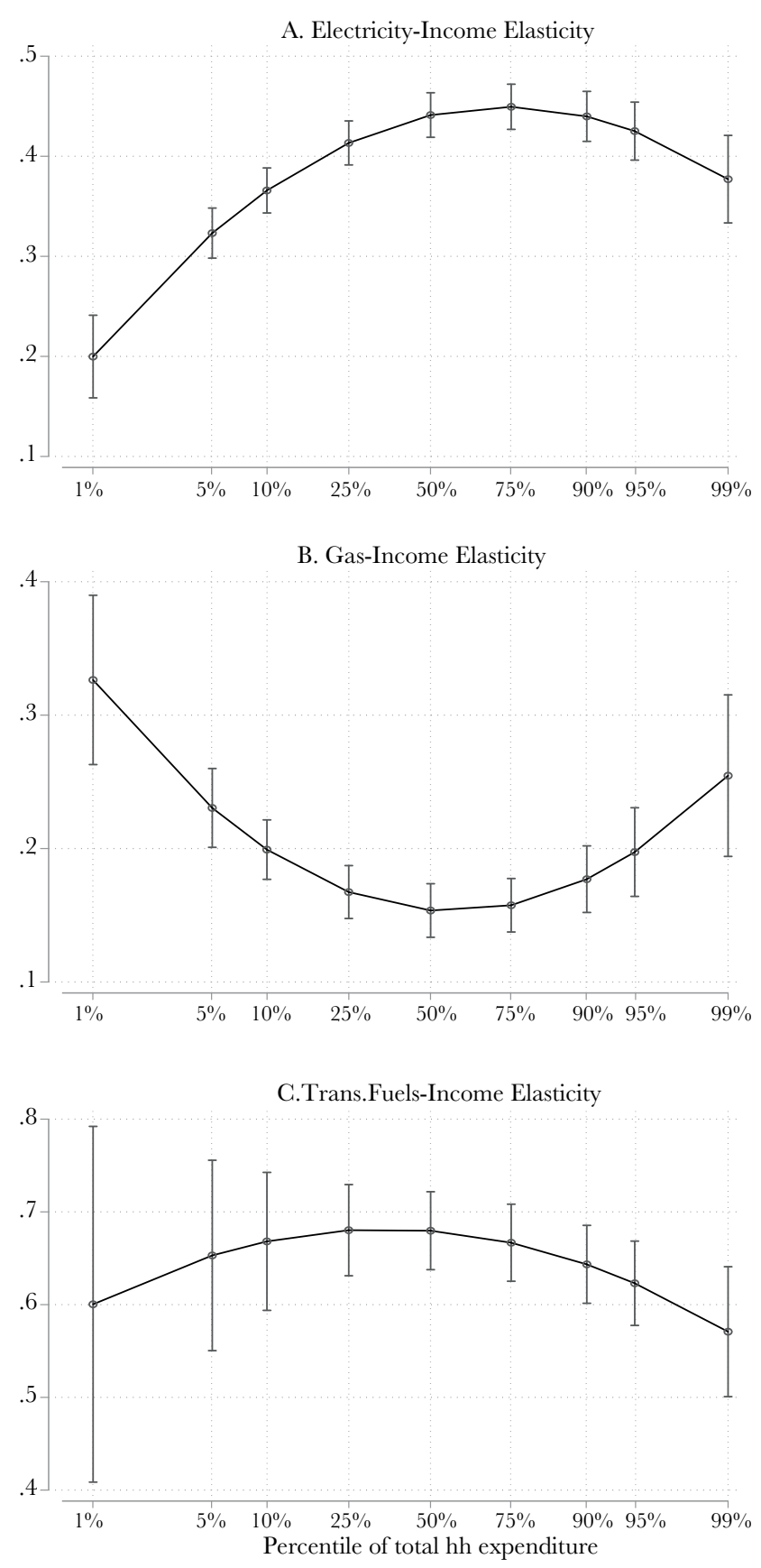

Source: Own elaboration.

Note: Estimated income elasticities at percentiles of household per capita total expenditure, with 95\% confidence interval. Calculations derive from the best fit polynomial for each fuel, see Annex B. 


\section{Conclusions}

We used a comprehensive dataset of households in 13 Latin American countries to study the determinants of energy expenditure, with a focus on its relationship with income and the presence of EOS. Specifically, we address the link between energy expenditures -electricity, domestic gas, and transport- and household location, family composition, dwelling size, durable goods ownership, and income. Altogether, our findings highlight the relevance of these variables in shaping energy spending and affordability, but with important differences between fuels.

Domestic fuels expenditures and budget shares are driven by household socioeconomic characteristics. Household location (urban/rural) and appliances ownership explain more than 50 percent of energy expenditures. At the same time, while fuel expenditure is strongly positively correlated with income; its weight in the family budget tends to decrease to the right of the income distribution, indicating that energy expenditure grows at a lower rate than income. On the other hand, the materialization of EOS of household size is clearer than for dwelling size, and further, it is more pronounced in wealthier households.

The estimated conditional Engel curves have similar shapes between fuels; however, we observe noticeable differences in the path of income elasticity by fuels. Although these elasticities are less than unity for all fuels, they tend to be higher, across all income groups, for transport fuel, followed by electricity and domestic gas. For electricity, the elasticity monotonically increases with income, to decline after the 75th percentile. For gas, it follows a $\mathrm{u}$-shape over the income range of our sample. For transport fuel, it increases up to the 25th percentile, and then begins to decrease. Although these results portray electricity, domestic gas, and even transport fuels as necessity goods, it is important to take into account that the richer segments concentrate most of the residential energy expenditure, especially in the case of liquid fuels.

To the extent that the observed energy spending patterns reflect energy consumption, our findings may have implications for energy efficiency and conservation policies. These results imply that demographic and construction trends impact both energy-spending and -consumption patterns. The detected EOS suggest that energy efficiency policies for housing and buildings may have significant effects not only on energy consumption, but also on related expenditures, relieving household budgets. Similarly, given the sizeable explanatory power -on energy expenditures- of ownership of appliances and cars, these implications extend to the implementation of energy efficiency standards for durable goods. These results suggest that such policies not only would save energy, but also would increase affordability, which would have a greater effect on the poorer groups.

\section{References}

Advani, A., Johnson, P., Leicester, A., \& Stoye, G. (2013). Household Energy Use in Britain: A Distributional Analysis. London: Institute for Fiscal Studies, Report R85. https://www.ifs.org.uk/ comms/r85.pdf

Bacon, R., Bhattacharya, S., \& Kojima, M. (2010). Expenditure of Low-Income Households on Energy: Evidence from Africa and Asia. Washington, DC: World Bank. https://www.researchgate. net/publication/265884784 Expenditure of Low-Income Households on Energy Evidence from

Baker, P., Blundell, R., \& Micklewright, J. (1989). Modelling Household Energy Expenditures Using Micro-Data. The Economic Fournal, 99(397), 720. https://doi. org/10.2307/2233767 
Banks,J., Blundell, R., \& Lewbel, A. (1997). Quadratic Engel Curves and Consumer Demand. Review of Economics and Statistics, 79(4), 527-539. https://doi.org/10.1162/003465397557015

Benus, J., Kmenta, J., \& Shapiro, H. (1976). The Dynamics of Household Budget Allocation to Food Expenditures. The Review of Economics and Statistics, 58(2), 129. https://doi. org/10.2307/1924018

Borenstein, S. (2012). The Redistributional Impact of Nonlinear Electricity Pricing. American Economic Fournal: Economic Policy, 4(3), 56-90. https://doi.org/10.1257/pol.4.3.56

BP (British Petroleum). (2016). BP Energy Outlook - 2016 Edition - Outlook to 2035. https:/ /www. bp.com/content/dam/bp/business-sites/en/global/corporate/pdfs/energy-economics/ energy-outlook/bp-energy-outlook-2016.pdf

Cayla, J.-M., Maizi, N., \& Marchand, C. (2011). The role of income in energy consumption behaviour: Evidence from French households data. Energy Policy, 39(12), 7874-7883. https:// doi.org/10.1016/j.enpol.2011.09.036

Coady, D., Parry, I., Sears, L., \& Shang, B. (2017). How Large Are Global Fossil Fuel Subsidies? World Development, 91, 11-27. https://doi.org/10.1016/j.worlddev.2016.10.004

De Luca, G., \& Peracchi, F. (2011). Estimating Engel curves under unit and item nonresponse. Journal of Applied Econometrics, 27(7), 1076-1099. https://doi.org/10.1002/jae.1232

Deaton, A., \& Paxson, C. (1998). Economies of Scale, Household Size, and the Demand for Food. Fournal of Political Economy, 106(5), 897-930. https://doi.org/10.1086/250035

Di Bella, G., Norton, L., Ntamatungiro, J., Ogawa, S., Samake, I., \& Santoro, M. (2015). Energy Subsidies in Latin America and the Caribbean: Stocktaking and Policy Challenges. IMF Working Paper 15/30. International Monetary Fund. https://www.imf.org/external/pubs/ft/wp/2015/wp1530.pdf

Estiri, H. (2015). The indirect role of households in shaping US residential energy demand patterns. Energy Policy, 86, 585-594. https://doi.org/10.1016/j.enpol.2015.08.008

Fankhauser, S., \& Tepic, S. (2007). Can poor consumers pay for energy and water? An affordability analysis for transition countries. Energy Policy, 35(2), 1038-1049. https://doi. org/10.1016/j.enpol.2006.02.003

Foster, V., Tre, J. P., \& Wodon, Q. (2000). Energy Consumption and Income: An Inverted-U at the Household Level? Washington, DC: World Bank. https://www.researchgate.net/publication/264999079 Energy consumption and income An inverted-U at the household level

Fouquet, R. (2014). Long-Run Demand for Energy Services: Income and Price Elasticities over Two Hundred Years. Review of Environmental Economics and Policy, 8(2), 186-207. https://doi. org/10.1093/reep/reu002

Geller, H., Harrington, P., Rosenfeld, A. H., Tanishima, S., \& Unander, F. (2006). Polices for increasing energy efficiency: Thirty years of experience in OECD countries. Energy Policy, 34(5), 556-573. https://doi.org/10.1016/j.enpol.2005.11.010

Hancevic, P. I., \& Lopez-Aguilar, J. A. (2019). Energy efficiency programs in the context of increasing block tariffs: The case of residential electricity in Mexico. Energy Policy, 131, 320331. https://doi.org/10.1016/j.enpol.2019.04.015

Hanna, R., \& Oliva, P. (2015). Moving up the Energy Ladder: The Effect of an Increase in Economic Well-Being on the Fuel Consumption Choices of the Poor in India. American Economic Review, 105(5), 242-246. https://doi.org/10.1257/aer.p20151097

Heltberg, R. (2004). Fuel switching: evidence from eight developing countries. Energy Economics, 26(5), 869-887. https://doi.org/10.1016/j.eneco.2004.04.018 
Ironmonger, D. S., Aitken, G. K., \& Erbas, B. (1995). Economies of scale in energy use in adult-only households. Energy Economics, 17(4), 301-310. https://doi.org/10.1016/0140$\underline{9883(95) 00032-p}$

Jamasb, T., \& Meier, H. (2010). Household Energy Expenditure and Income Groups: Evidence from Great Britain. University of Cambridge. https://www.repository.cam.ac.uk/bitstream/handle $/ 1810 / 229412 / 1011 \% 26$ EPRG 1003.pdf? sequence $=2 \&$ isAllowed $=\mathrm{y}$

Jimenez, R., Macedo, D., \& Yepez-Garcia, A. (2018). Composition and Sensitivity of Residential Energy Consumption. Washington, DC: Mimeo.

Kay, J. A., Keen, M. J., \& Morris, C. N. (1984). Estimating consumption from expenditure data. Journal of Public Economics, 23(1-2), 169-181. https://doi.org/10.1016/00472727(84)90071-9

Longhi, S. (2015). Residential energy expenditures and the relevance of changes in household circumstances. Energy Economics, 49, 440-450. https://doi.org/10.1016/j.eneco.2015.03.018

Marchioni, M., Sosa-Escudero, W., \& Alejo, J. (2008). La Incidencia Distributiva del Acceso, Gasto y Consumo de los Servicios Públicos. Documento de Trabajo Núm. 67, UNLP: CEDLAS. https://www.researchgate.net/publication/4809760 La Incidencia Distributiva del Acceso Gasto y Consumo de los Servicios Publicos

Martins, R., Quintal, C., Cruz, L., \& Barata, E. (2016). Water affordability issues in developed countries - The relevance of micro approaches. Utilities Policy, 43, 117-123. https://doi. org/10.1016/j.jup.2016.04.012

Meier, H., Jamasb, T., \& Orea, L. (2013). Necessity or Luxury Good? Household Energy Spending and Income in Britain 1991-2007. The Energy Fournal, 34(4), 109-129. https:// doi.org/10.5547/01956574.34.4.6

Meyers, S., McMahon,J. E., McNeil, M., \& Liu, X. (2003). Impacts of US federal energy efficiency standards for residential appliances. Energy, 28(8), 755-767. https://doi.org/10.1016/ $\underline{\text { s0360-5442(02)00188-3 }}$

Navajas, F. (2013). The Social Efficiency of Energy Access. 4th Latin American Meeting of Energy Economics (ELAEE). Montevideo, April 8-9, 2013. http://www.fiel.org/publicaciones/ Novedades/NEWS 1367351676343.pdf

Navajas, F. H. (2009). Engel curves, household characteristics and low-user tariff schemes in natural gas. Energy Economics, 31(1), 162-168. https://doi.org/10.1016/j.eneco.2008.09.005

Nelson, J. A. (1988). Household Economies of Scale in Consumption: Theory and Evidence. Econometrica, 56(6), 1301. https://doi.org/10.2307/1913099

Nicoletti, G., \& Peracchi, F. (2005). Survey response and survey characteristics: microlevel evidence from the European Community Household Panel. Fournal of the Royal Statistical Society: Series A (Statistics in Society), 168(4), 763-781. https://doi.org/10.1111/j.1467985x.2005.00369.x

Pachauri, S., \& Jiang, L. (2008). The household energy transition in India and China. Energy Policy, 36(11), 4022-4035. https://doi.org/10.1016/j.enpol.2008.06.016

Poyer, D. A., Henderson, L., \& Teotia, A. P. S. (1997). Residential energy consumption across different population groups: comparative analysis for Latino and non-Latino households in USA. Energy Economics, 19(4), 445-463. https://doi.org/10.1016/s0140-9883(97)01024-4

Pudney, S., \& Francavilla, F. (2006). Income mis-measurement and the estimation of poverty rates: an analysis of income poverty in Albania. ISER Working Paper Series 2006-35, University of Essex. https://www.iser.essex.ac.uk/research/publications/working-papers/iser/2006-35 
Underwood, A., \& Zahran, S. (2015). The carbon implications of declining household scale economies. Ecological Economics, 116, 182-190. https://doi.org/10.1016/j.ecolecon.2015.04.028

Winkler, H., Simões, A. F., Rovere, E. L., Alam, M., Rahman, A., \& Mwakasonda, S. (2011). Access and Affordability of Electricity in Developing Countries. World Development, 39(6), 1037-1050. https://doi.org/10.1016/j.worlddev.2010.02.021

Wolfram, C., Shelef, O., \& Gertler, P. (2012). How Will Energy Demand Develop in the Developing World? Fournal of Economic Perspectives, 26(1), 119-138. https://doi.org/10.1257/ jep.26.1.119

\section{List of Abbreviations}

BP: British Petroleum

EOS: Economies of Scale

HH: Households

LAC: Latin America and the Caribbean

PG: Per Capita

PPP: Purchasing Power Parity

Q\#: Per capita income quintile \#

US\$: Dollars from United States of America

WDI: World Development Indicators

\section{Declarations}

Availability of data and material

The code and dataset used in this paper is available at: $\underline{\text { ttps: } / / \mathrm{t} . \mathrm{co} / \mathrm{tfCHITJ} 5 \mathrm{~d} \text { ?amp }=1}$

Competing interests

The authors declare that they have no competing interests.

Funding

Not applicable.

Authors' Contributions

Both authors read and approved the final manuscript.

\section{Acknowledgements}

This version (September 2020) has benefited from comments and suggestions of Andrea Guerrero, Demian Macedo and two anonymous peer-reviewers. All remaining errors are our own responsibility. The findings, interpretations, and conclusions herein are strictly those of the authors and should not be attributed in any manner to their affiliated institutions.

\section{Authors' Information}

Raul Jimenez Mori: IDB Invest. Corresponding author: rjmori@gmail.com.

Ariel Yepez-Garcia: Inter-American Development Bank. Energy Division. 


\section{Annex A: Sources}

\begin{tabular}{|c|c|c|c|c|}
\hline Countries & Survey Name & Year & Obs. & $\begin{array}{l}\text { \# indicators for } \\
\text { fixed effects }\end{array}$ \\
\hline Bolivia & Encuesta de Hogares & 2013 & 8585 & 9 \\
\hline Brazil & Pesquisa de Orçamentos Familiares & $2008 / 2009$ & 53098 & 27 \\
\hline Costa Rica & Encuesta Nacional de Ingresos y Gastos & 2013 & 2499 & 6 \\
\hline Dom. Republic & $\begin{array}{l}\text { Encuesta Nacional de Ingresos y Gastos de los } \\
\text { Hogares }\end{array}$ & 2007 & 5943 & 32 \\
\hline Ecuador & $\begin{array}{l}\text { Encuesta Nacional de Ingresos y Gastos de los } \\
\text { Hogares Urbanos y Rurales }\end{array}$ & $2011 / 2012$ & 37293 & 24 \\
\hline Guatemala & $\begin{array}{l}\text { Encuesta Nacional de Ingresos y Gastos Fami- } \\
\text { liares }\end{array}$ & $2009 / 2010$ & 7818 & 22 \\
\hline Honduras & Encuesta Nacional de Condiciones de Vida & 2004 & 4570 & 28 \\
\hline Jamaica & Jamaica Survey of Living Conditions & 2012 & 5166 & 14 \\
\hline Mexico & $\begin{array}{l}\text { Encuesta Nacional de Ingreso-Gasto de los } \\
\text { Hogares }\end{array}$ & 2014 & 17573 & 506 \\
\hline Nicaragua & $\begin{array}{l}\text { Encuesta Nacional de Hogares sobre Medi- } \\
\text { ción de Nivel de Vida }\end{array}$ & 2014 & 5761 & 4 \\
\hline Paraguay & $\begin{array}{l}\text { Encuesta de Ingresos y Gastos y de Condicio- } \\
\text { nes de Vida }\end{array}$ & $2011 / 2012$ & 4553 & 16 \\
\hline Peru & $\begin{array}{l}\text { Encuesta Nacional de Hogares sobre Condi- } \\
\text { ciones de Vida y Pobreza }\end{array}$ & 2014 & 23625 & 35 \\
\hline Uruguay & $\begin{array}{l}\text { Encuesta Nacional de Gastos e Ingresos de los } \\
\text { Hogares }\end{array}$ & $2005 / 2006$ & 6367 & 19 \\
\hline
\end{tabular}

Source: Own elaboration. 


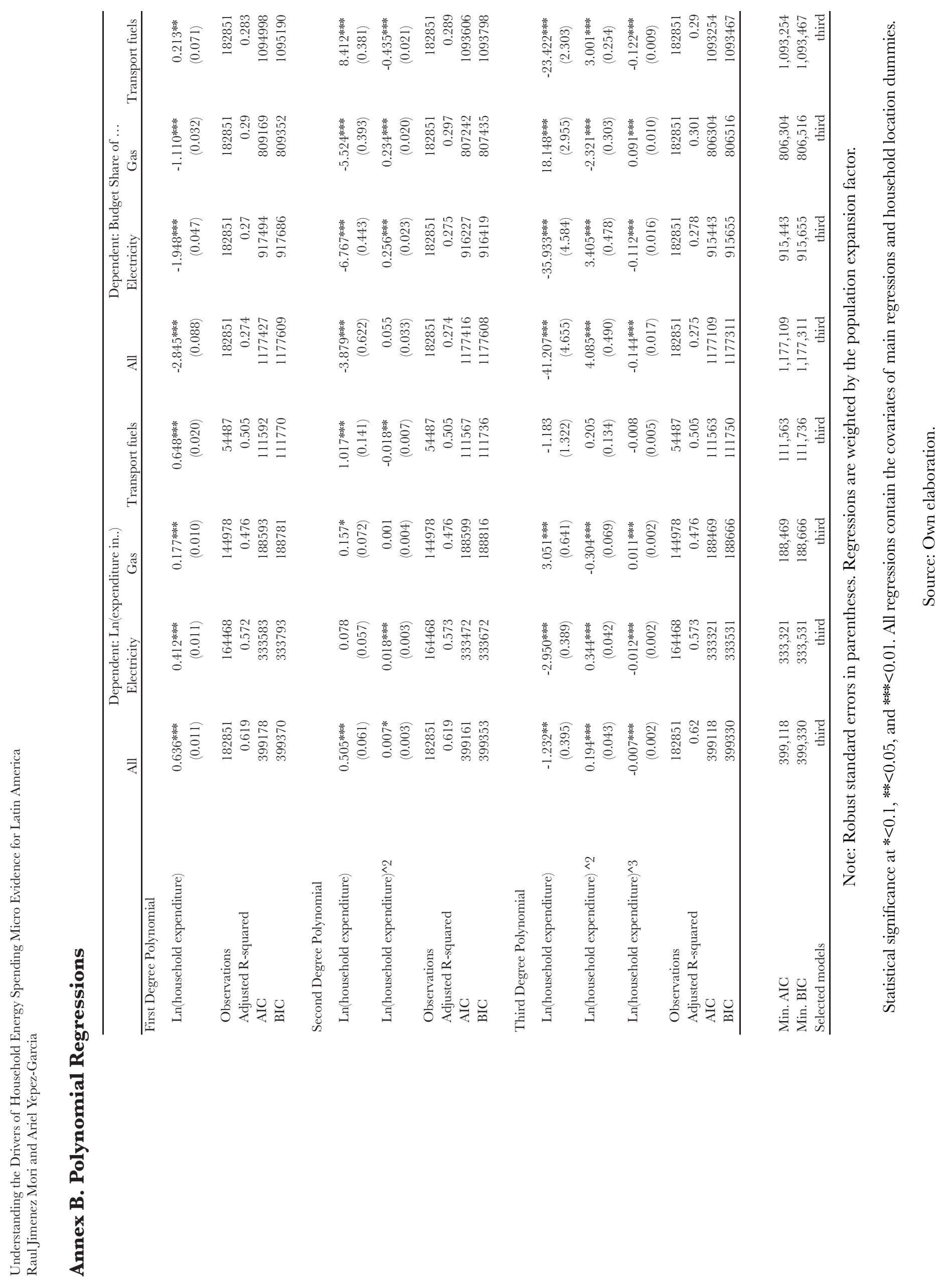




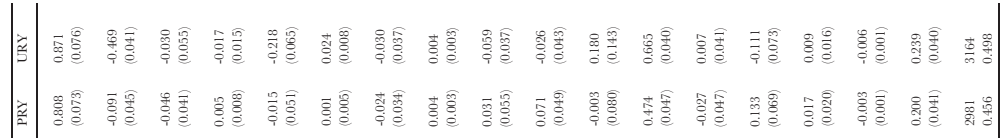

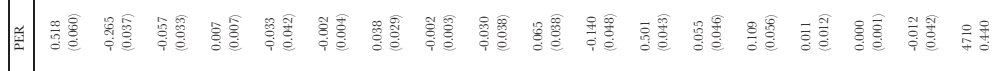

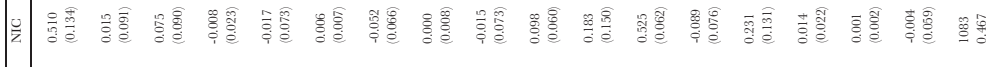

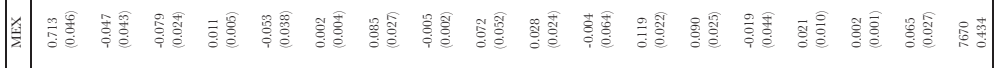

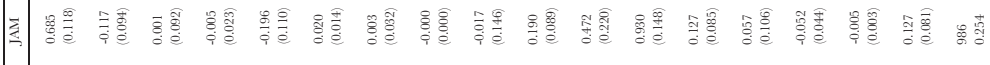

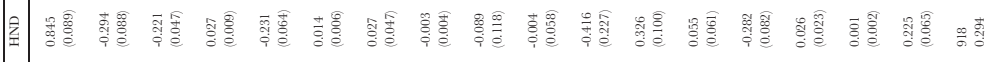

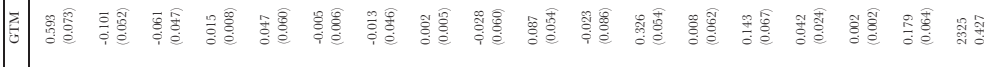

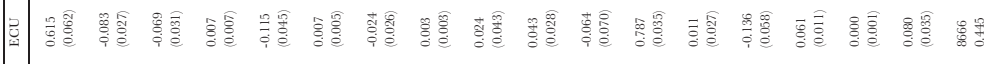

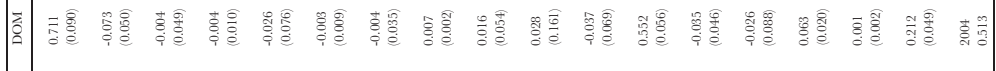

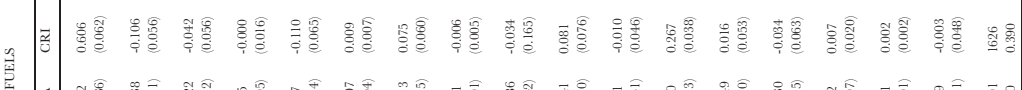

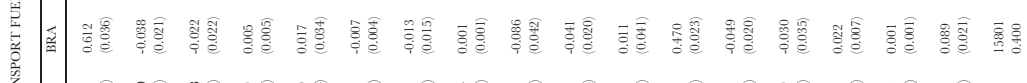

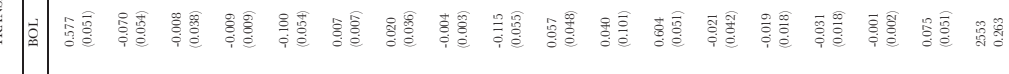

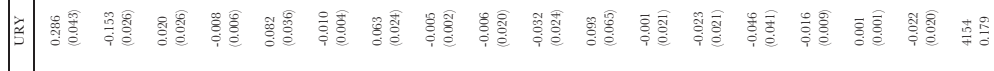

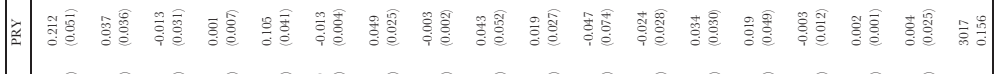

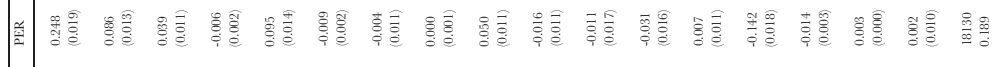

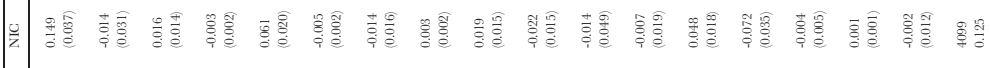

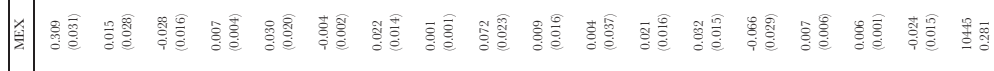

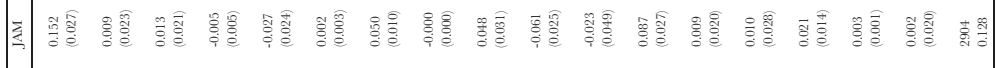

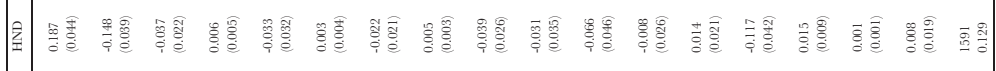

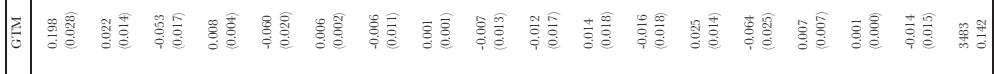

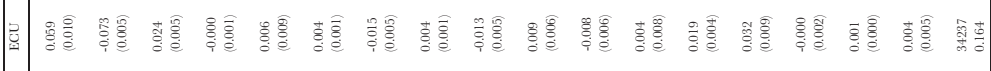

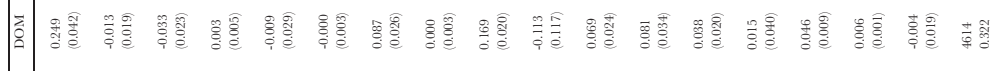

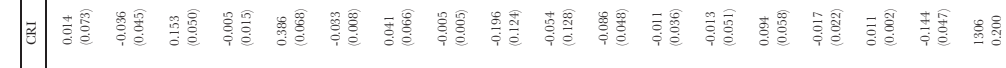

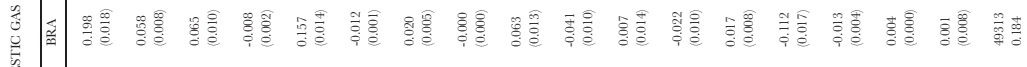

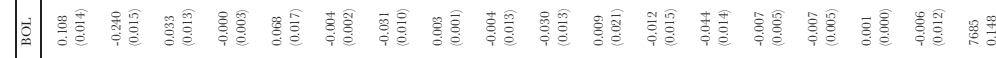

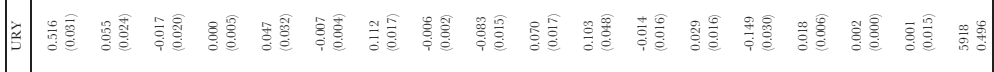

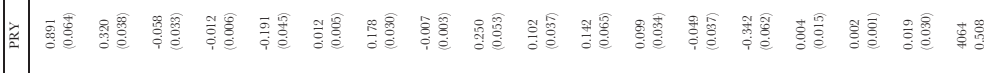

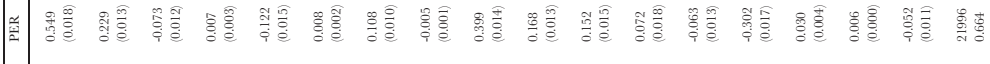

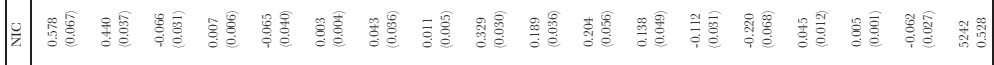

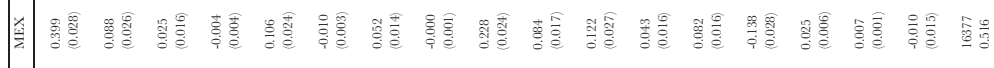

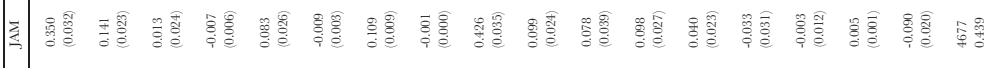

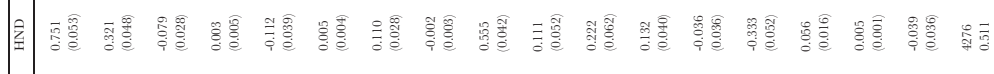

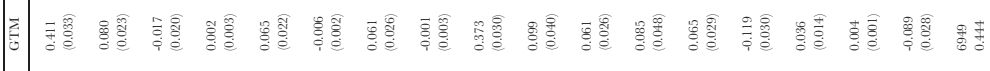

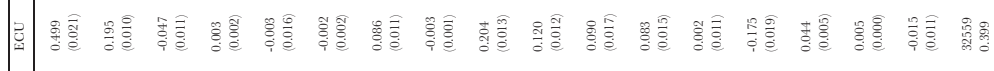

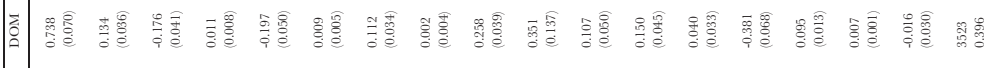

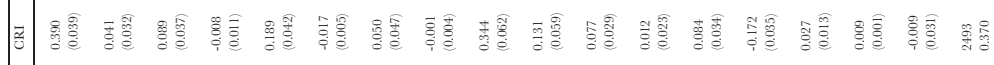

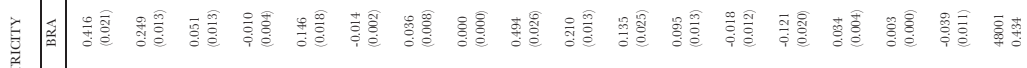

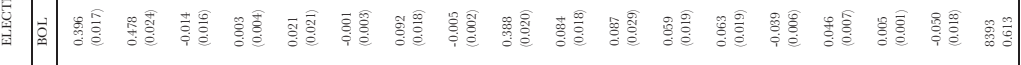
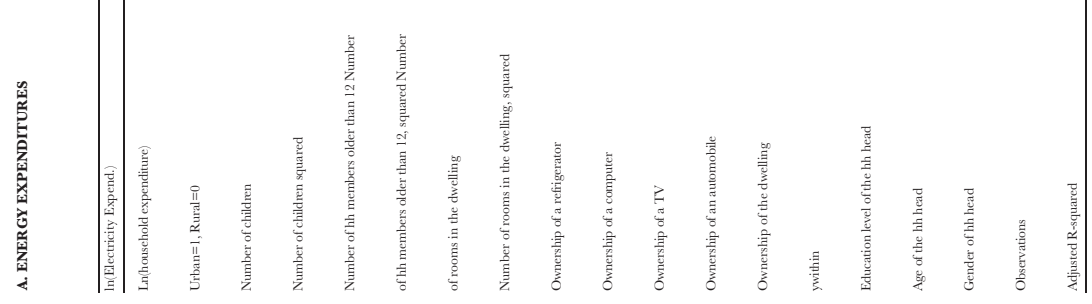


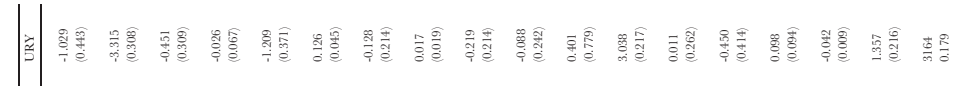

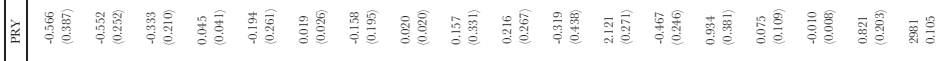

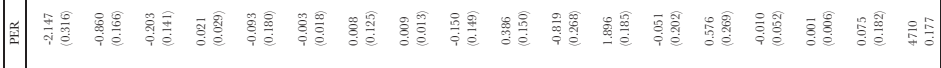

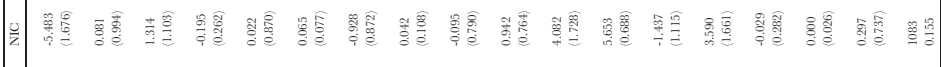

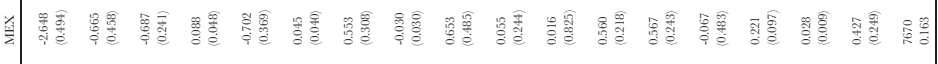

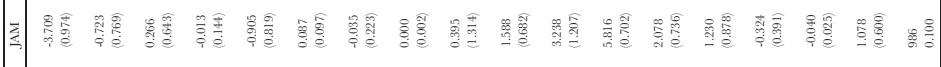

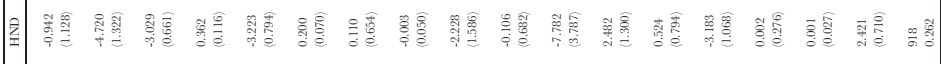

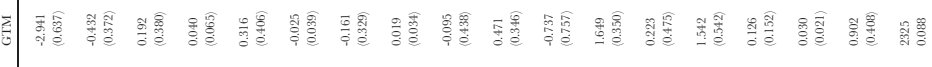

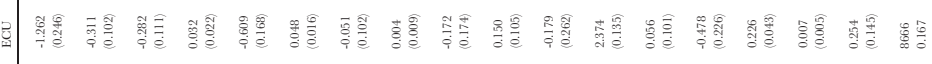

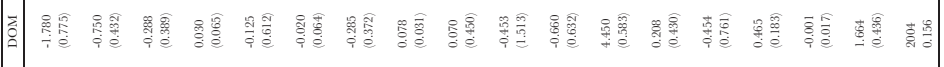

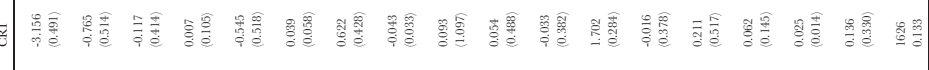

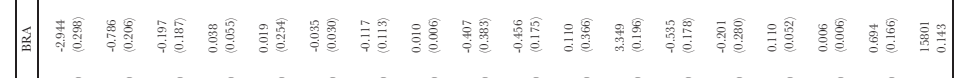

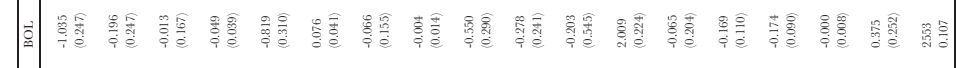

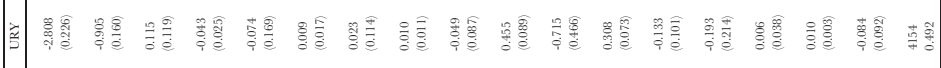

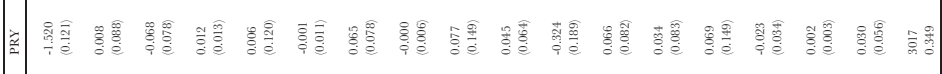

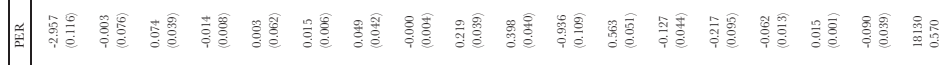

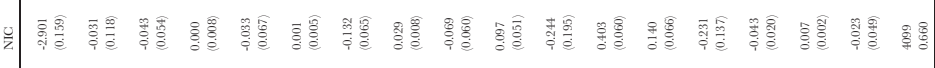

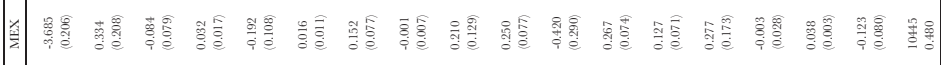

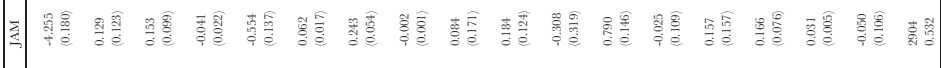

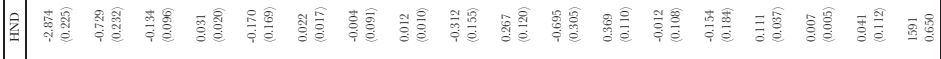

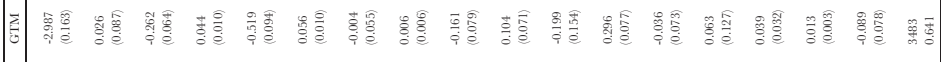

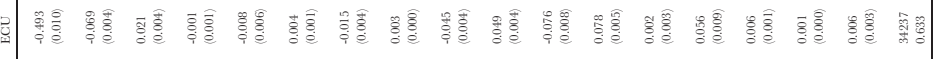

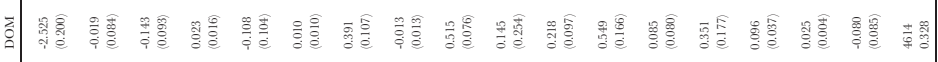

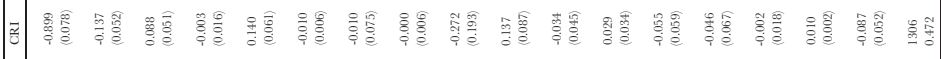

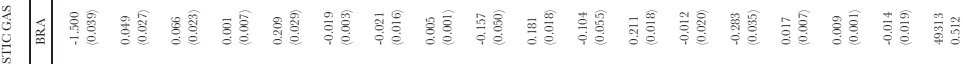

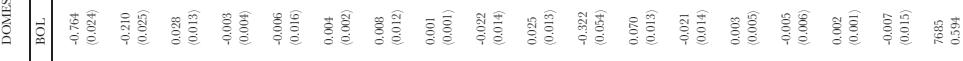

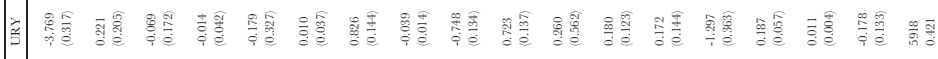

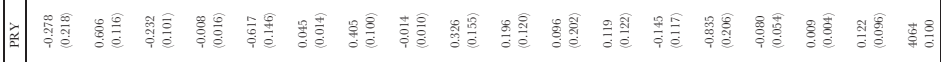

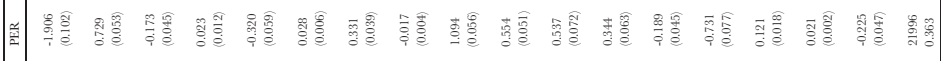

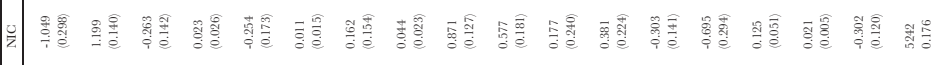

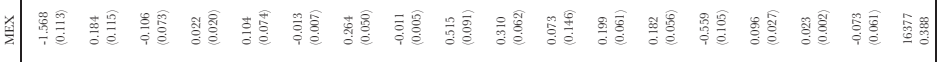

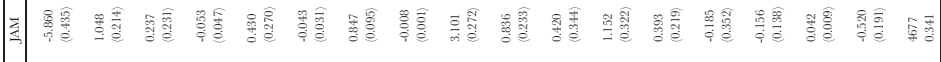

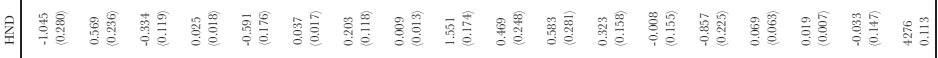

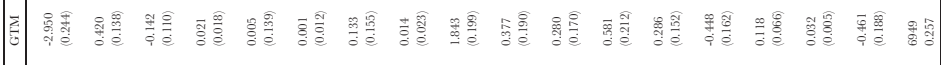

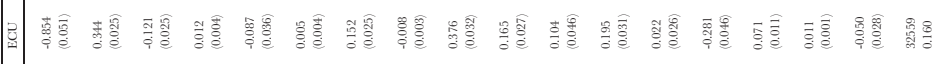

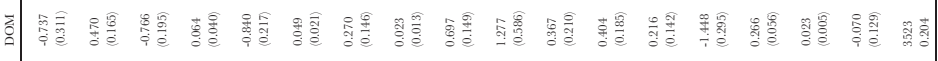

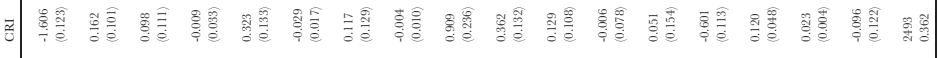

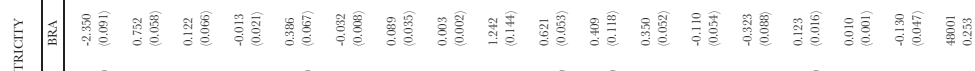

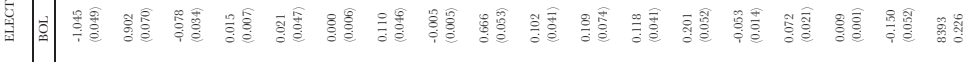




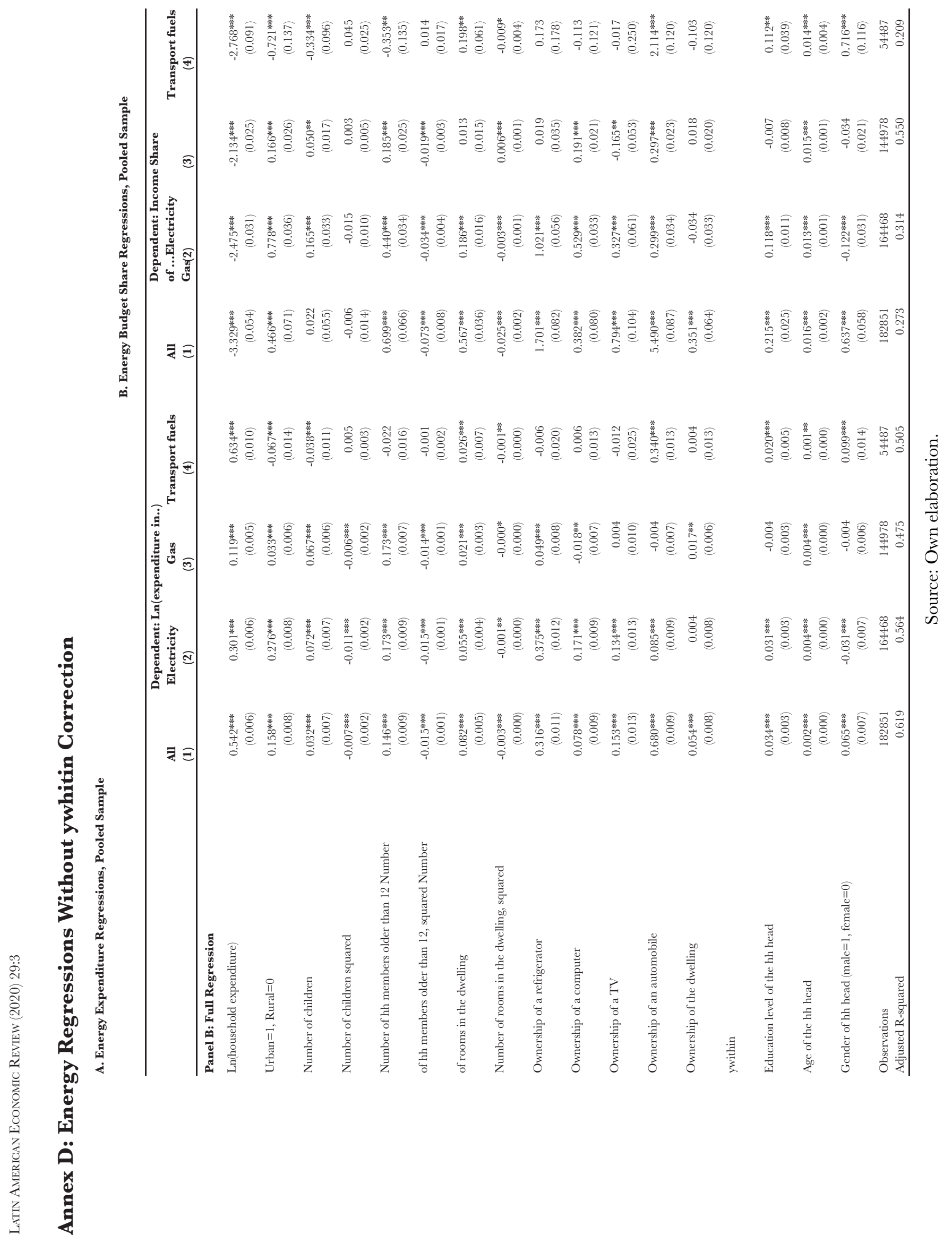

